Review

\title{
Synthesis of sex hormone-derived modified steroids possessing antiproliferative activity
}

\author{
Éva Frank, Gyula Schneider* \\ Department of Organic Chemistry, University of Szeged, Dóm tér 8, H-6720 Szeged, Hungary
}

\section{A R T I C L E I N F O}

\section{Article history:}

Received 27 November 2012

Received in revised form 7 February 2013

Accepted 27 February 2013

\section{Keywords:}

Steroid

Modified sex hormones

Synthesis

Antiproliferative activity

\begin{abstract}
A B S T R A C T
During recent years intensive research has been focused on the synthesis of structurally modified steroid hormones in order to obtain compounds with beneficial biological activity such as cell-growth inhibition. Experimental results have revealed that some steroidal derivatives possess direct cytostatic effect on cancer cells in a hormone receptor-independent manner. After a brief account on the most important biological function and characteristics of the naturally occurring sex hormones in physiological and pathological conditions, structural modifications of estrane and androstane scaffolds are discussed in detail. The review covers literature publications (from 2002 to 2012) relating to the synthesis and antiproliferative activity of semisynthetic sex hormone-derived molecules containing simple or heterocyclic substituents. The compounds reviewed are divided into three main categories according to their sterane framework and the nature of substitution.

This article is part of a Special Issue entitled "Synthesis and biological testing of steroid derivatives as inhibitors".
\end{abstract}

(c) 2013 Published by Elsevier Ltd.

\section{Contents}

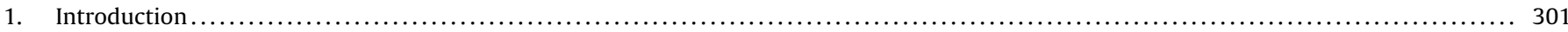

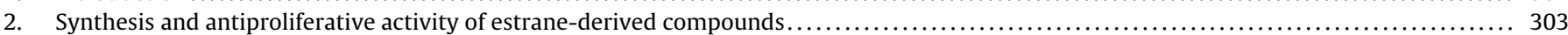

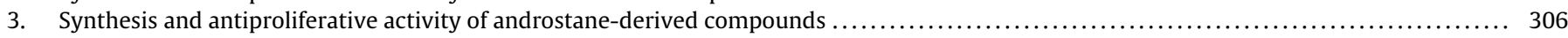

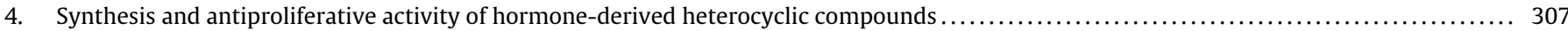

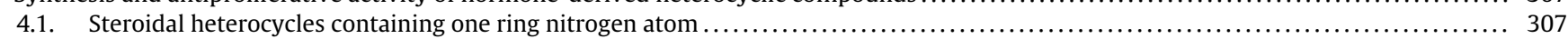

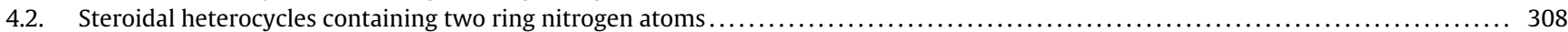

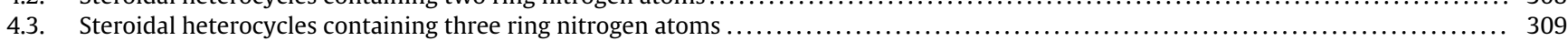

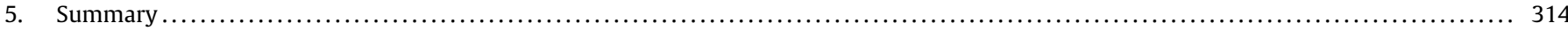

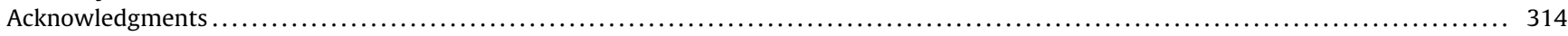

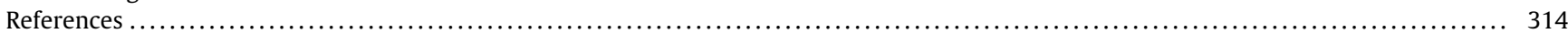

\section{Introduction}

Natural sex hormones, i.e. androgens, estrogens and progestogens, which are produced primarily by the gonads and in smaller amounts by the adrenal glands and other tissues, exert a wide range of biological effects on the body, affecting the growth and function of the reproductive organs and the development of secondary sexual characteristics. Androgens are also the original anabolic steroids and the precursors of all estrogens, which (together with progesterone) play a major role in the regulation of the menstrual cycle and pregnancy. Thanks to their nonpolar and hydrophobic sterane

\footnotetext{
* Corresponding author. Tel.: +36 62 544276; fax: +36 62544200 .

E-mail address: schneider@chem.u-szeged.hu (G. Schneider).
}

framework, steroid hormones can easily penetrate through the cell membranes and interact with their specific intracellular receptors, either in the cytosol or in the nucleus of the target cells. Through this slow genomic mechanism, the ligand-receptor complex acts as a transcription factor in the nucleus, augmenting or suppressing particular transcription genes by its action on DNA [1]. Recent studies suggest, however, that the effects of steroid hormones can also be mediated by fast nongenomic mechanisms through membrane-associated receptors and signaling cascades [2]. As a result of extensive structure-activity relationship (SAR) studies, a considerable amount of information is available concerning the structural features of the intracellular receptors, the pharmacophore moiety of the ligands and hormone-receptor binding [3-5]. Besides hydrophobic interactions, hydrogen-bonding in some regions of the steroid binding pocket is also involved in the 


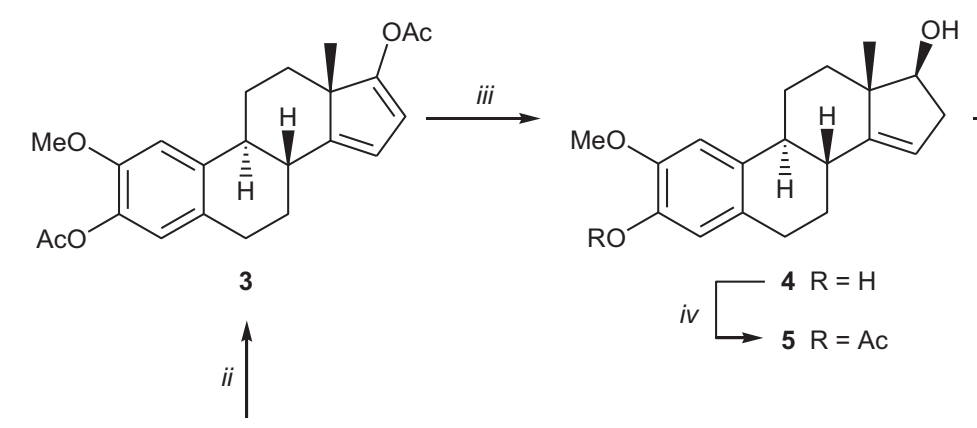<smiles>COc1cc2c(cc1OC(C)(C)C)[C@@H]1CC[C@]3(C)C(=O)CC=C3[C@@H]1CC2</smiles><smiles>COc1cc2c(cc1O)CC[C@@H]1[C@@H]2C=CC(=O)C1(C)C</smiles><smiles>COc1cc2c(cc1O)CC[C@@H]1[C@@H]2C=C[C@H](O)C1(C)C</smiles>

10

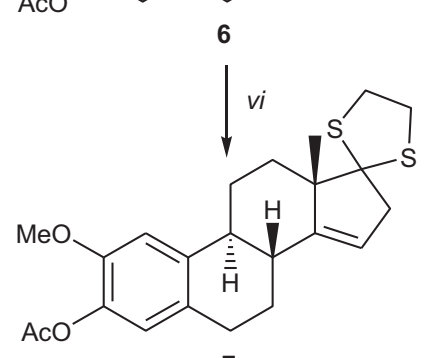

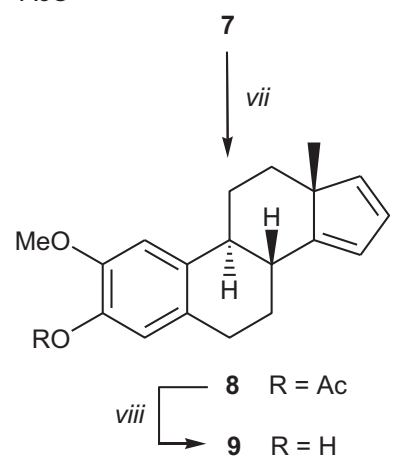

$$
\mathrm{RO}
$$<smiles>[R]=CCCCC</smiles><smiles>CCCCCCCC</smiles>

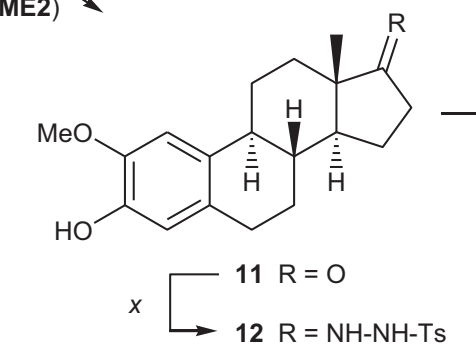

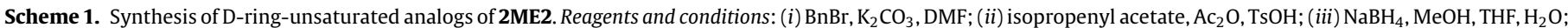

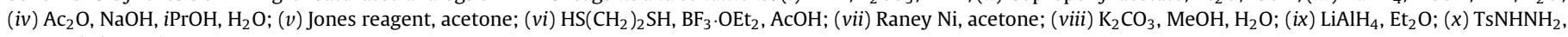
$\mathrm{MeOH}$; $(x i) n \mathrm{BuLi}$, THF.

binding mechanism. All semisynthetic modifications involving the apolar sterane skeleton or the polar functional groups at C-3 and C-17 in the natural hormones may exert a significant influence on the binding affinity of the molecule.

In consequence of the important functions of steroid hormones, they and their modified analogs have been applied exogenously to humans in order to attain certain benefits in health or even to improve physical and growth performance. Estrogens and progestogens are administered as components of oral contraceptives and in hormone replacement therapy, while androgens are used to correct natural hormone deficiencies and to reduce "male menopause" symptoms such as the lack of sex drive, anxiety and depression. Furthermore, extensive effort has been devoted to the synthesis of potentially therapeutic derivatives providing enhanced anabolic potency with reduced androgenic effects, though with only modest success [4].

In addition to the modulation of normal development and maintenance of the reproductive tract, sex steroids play a crucial role in the malignant growth of these organs [6]. As steroid hormones are powerful drivers of the gene expression in hormone-dependent cancer cells, changes in the levels or activities of certain hormones can cause these cancers to cease growing, or even undergo cell death. Hormonal therapy is therefore one of the major possibilities for the medical treatment of cancer, involving manipulation of the endocrine system through the exogenous administration of steroid hormones, or drugs which inhibit the production or activity of the endogenous ligand. Thus, a number of modified steroid molecules have been described as potent inhibitors of specific enzymes involved in the biosynthesis of sex hormones, allowing their potential use in the medication of hormone-dependent diseases. Steroidal exo-heterocycles, for example, such as the therapeutically used abiraterone, can block androgen synthesis at an early stage by inhibiting $17 \alpha$-hydroxylase $/ \mathrm{C}_{17,20}$-lyase $\left(\mathrm{P} 450_{17 \alpha}\right)$ and can therefore be effective in the treatment of prostate cancer [7-11]. Moreover, some drugs exert their biological activity as aromatase inhibitors by reducing estrogen production and can thus be applied in the treatment of estrogen receptor-positive $(\mathrm{ER}+)$ breast cancer $[12,13]$. Another approach in cancer therapy is the application of antagonists which bind to the receptor of a given hormone, thereby preventing its activation. However, the effectiveness of these drugs is limited by their partial agonist properties, which can cause undesirable side-effects [14]. Experimental 

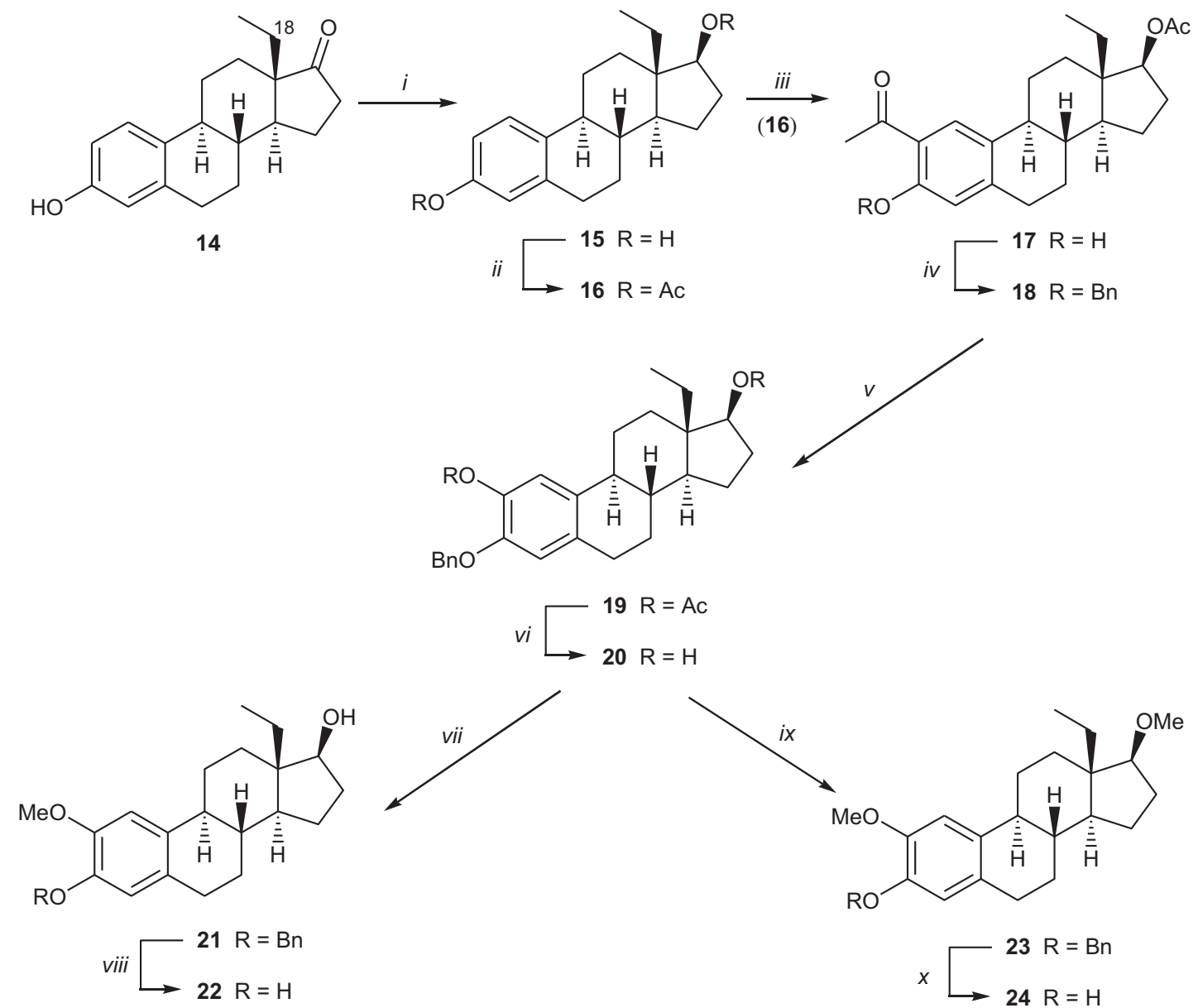

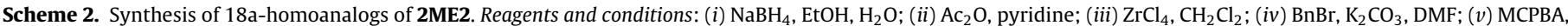
$\mathrm{Na}_{2} \mathrm{HPO}_{3}, \mathrm{CH}_{2} \mathrm{Cl}_{2}$; (vi) NaOH, MeOH, $\mathrm{H}_{2} \mathrm{O}$; (vii) LiOH. $\mathrm{H}_{2} \mathrm{O}, \mathrm{Me}_{2} \mathrm{SO}_{4}$, THF; (viii) $\mathrm{H}_{2}, \mathrm{Pd} / \mathrm{C}, \mathrm{EtOH} ;($ ix $) \mathrm{NaH} / \mathrm{THF}, \mathrm{MeI} ;(x) \mathrm{H}_{2}$, Pd/C, EtOH.

results achieved during the past few years have revealed that some steroidal derivatives play important roles in complex signal transduction mechanisms in a hormone receptor-independent manner by the inhibition of angiogenesis, tubulin polymerization and the upregulation of apoptotic pathways. The main advantage of this mode of action is that such compounds may offer a solution for the therapy of hormone-resistant cancers. The most important candidate in this class is 2-methoxyestradiol $\left(\mathbf{2} \mathbf{M E}_{2}\right)$, an endogenous metabolite of $17 \beta$-estradiol, which has been shown to be effective in preventing tumor growth in a variety of cell lines of diverse origins [15-21]. Although the exact mechanism of action is still unclear, the unique antiproliferative and apoptotic activities of $\mathbf{2} \mathbf{M E}_{\mathbf{2}}$ are mediated independently of the estrogen receptors [22,23].

A major challenge in semisynthetic steroid chemistry at present is the development of novel derivatives with a biological target other than a hormone receptor, and therefore the reduction or elimination of undesirable hormonal activity. The synthetic tools for the attainment of this goal are: (a) the synthesis of molecules lacking the functionalities necessary for effective binding to the hormone receptors [24]; (b) modification of the binding ability by chemical transformation of the functional groups already present [3]; (c) steric hindrance of the substrate-receptor interaction by chemical substitution near the original groups [19]; (d) altering the primary stereostructure or the number of ring members [25]; and (e) the design of heterocyclic derivatives that are not recognized by the receptor protein in consequence of their specific structure or the fact that their geometry differs from that of the natural hormones
[26]. However, some combination of the above strategies may likewise be an effective route for the development of novel derivatives with potent therapeutic activity.

The present review mainly focuses on the syntheses and brief pharmacological studies of hormone-derived molecules containing different substituents, including various side-chains or heterocyclic moieties, fused to or linked to the original sterane framework, which have been reported to exhibit an in vitro cell growthinhibitory effect on malignant tumor cell lines.

\section{Synthesis and antiproliferative activity of estrane-derived compounds}

2ME2 has been evaluated under the name Panzem ${ }^{\circledR}$ in several clinical trials. The clinical results demonstrated that 2ME2 is metabolized principally in oxidative and conjugation processes involving oxidation of the 17-hydroxy group and glucuronidation of both the 3- and 17-hydroxy functions [27]. These transformations lead to a rapid decrease in the concentration of the active drug, resulting in its low bioavailability. Moreover, in vitro metabolism studies have indicated that the methoxy moiety of 2ME2 can be removed oxidatively by the action of cytochromes P450 to form 2-hydroxyestradiol, which could be estrogenic in vivo. Thus, appreciable efforts have been made to synthesize modified analogs with an enhanced ability to inhibit tubulin polymerization or with an antiproliferative effect, but if possible without estrogenic activity, thereby providing an improvement in the metabolic profile. In attempts to elucidate the determinants of 2ME2 activity and to 


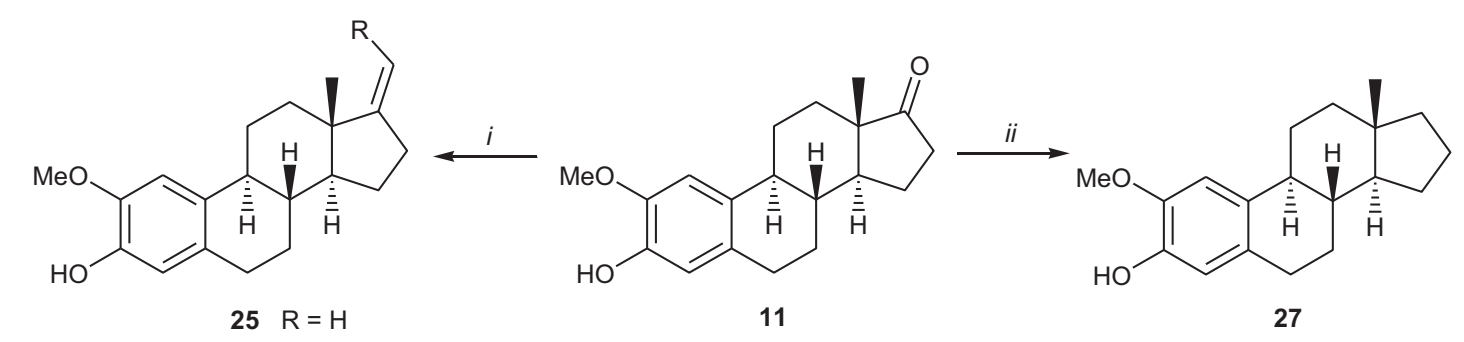

$26 \mathrm{R}=\mathrm{CH}_{3}$<smiles>COc1cc2c(cc1NC#N)CC[C@@H]1[C@@H]2CC[C@]2(C)[C@H](O)[C@@H](C)C[C@H]12</smiles>

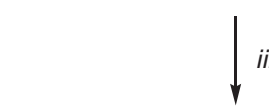<smiles>COc1cc2c(cc1NC(N)=O)CC[C@@H]1[C@@H]2CC[C@]2(C)[C@H](O)CC[C@H]12</smiles>

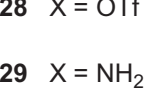<smiles>COc1cc2c(cc1C(N)=O)CC[C@@H]1[C@@H]2CC[C@@]2(C)[C@H]1CC[C@H]2O</smiles><smiles>[Y]N=NC(=O)O</smiles>

Scheme 3. Synthesis of 3- or 17-modified analogs of 2ME2. Reagents and conditions: (i) K-t-amylate, $\mathrm{RPPh}_{3} \mathrm{Br}$; (ii) hydrazine, $\mathrm{KOH}$, diethylene glycol, $n \mathrm{BuOH}$; (iii) $\mathrm{Tf}_{2} \mathrm{O}$, pyridine, $\mathrm{CH}_{2} \mathrm{Cl}_{2} ;$ (iv) (1) $\mathrm{Pd}(\mathrm{OAc})_{2}$, rac-BINAP, benzophenone imine, $\mathrm{Cs}_{2} \mathrm{CO}_{3}$, toluene, (2) $2 \mathrm{M} \mathrm{HCl}$, THF; $(v)(1) \mathrm{Pd}(\mathrm{OAc})_{2}$, rac $-\mathrm{BINAP}_{2} \mathrm{Cs}_{2} \mathrm{CO}_{3}, \mathrm{dppp}$, $\mathrm{HMDS}, \mathrm{DMF}, \mathrm{CO}$, (2) MeOH, then acidic workup, (3) $\mathrm{NaBH}_{4}$, MeOH; (vi) (1) $\mathrm{BrCN}, \mathrm{Et}_{2} \mathrm{O}, \mathrm{CH}_{2} \mathrm{Cl}_{2}$, (2) $\mathrm{NaBH}_{4}, \mathrm{MeOH}$; (vii) NaOCN, $\mathrm{H}_{2} \mathrm{O}, \mathrm{AcOH}$; (viii) $\mathrm{LiAlH}_{4}$ (1 M in THF); (ix) (1) formic acid, (2) NaOH, MeOH for 34a; $\mathrm{Ac}_{2} \mathrm{O}, \mathrm{NaOH}(10 \mathrm{M}$ aqueous) for $\mathbf{3 4 b}$.

prepare more efficacious analogs, structure-activity relationship (SAR) studies have been conducted by several research groups. Most of these studies have concentrated on modifying existing substituents or incorporating new substituents in rings A and D of 2ME2, although some B ring-expanded derivatives have also been found to exert noteworthy activity [28]. The introduction of an additional double-bond(s) into ring D of 2ME2 enhanced the in vitro antiproliferative activity on the MDA-MB-435 (human breast carcinoma) and SK-OV-3 (ovarian carcinoma) cell lines as compared with the parent molecule [29]. Compounds $\mathbf{4}$ and $\mathbf{1 0}$ were synthesized via well-known transformations from a common precursor 2, available from the 3-benzyloxy analog 1 [30] of 2ME2 (Scheme 1). Interestingly, some unsaturated derivatives $\mathbf{9}$ and $\mathbf{1 3}$, which lack the 17-hydroxy group, were also demonstrated to retain cell growth-inhibitory effects on both endothelial and tumor cells $[31,32]$. Moreover, in vitro metabolic stability studies have confirmed that these analogs are metabolically more stable than 2ME2 [32].

18a-Homoanalogs of 2ME2 synthesized by Rao et al. [33] from 14 via a multistep pathway (Scheme 2) and some of them, such as 22 and 24 were demonstrated to exhibit cytotoxic activity on MDA-MB-231 (human breast carcinoma), U87-MG (human gliomablastoma) and HUVEC (human umbilical vein endothelial) cells that was higher than or comparable to that of 2ME2. The introduction of a $\Delta^{14}$-bond in $\mathbf{2 2}$, however, significantly lowered the biological activity.
Structural modifications including ring D homologation and aromatization of the six-membered ring D to a chrysine-type molecule were also carried out through a cumbersome synthetic sequence to furnish novel derivatives with considerable antiproliferative effects [31].

Since the 3- and 17-hydroxy groups play a crucial role in the metabolic pathways of 2ME2, modifications of these functionalities have also been performed in order to obtain analogs with a retained or improved cell growth-inhibitory effect, but with diminished metabolic ability. The transformations depicted in Scheme 3 were carried out from 2-methoxyestrone (11) to furnish novel derivatives 25-27 lacking the 17-hydroxy moiety or containing an aminonitrile (31), urea (32), formamide (34a), carboxamide (30), amino (33) or acetamide (34b) group on C-3 [32,34]. All these compounds were found to exert diminished estrogenic activity, improved metabolic stability and increased or similar antiproliferative and antiangiogenic activity relative to $\mathbf{2 M E 2}$. It was concluded that, among other factors, the H-donating ability, the $\pi$-electronic character and the size of the $\mathrm{C}-3$ substituent all determine the biological activity.

The simultaneous modifications of positions 3 and 17 in 2ME2 also led to active analogs (Scheme 4) [35]. Compounds 13 and 25-27, obtained from 2-methoxyestrone (11) by Shapiro reduction (13), Wittig coupling (25 and 26) or Wolf-Kishner reduction (27) (Schemes 1 and 2), were used for the syntheses. All the synthesized derivatives represented by $\mathbf{4 0 - 4 2}$ and $\mathbf{4 5 - 4 7}$ exhibited marked cell 
<smiles>[R10]Oc1cc2c(cc1OC)[C@]1(C)CC[C@@]3(C)C([R])=CC[C@H]3[C@@H]1CC2</smiles>

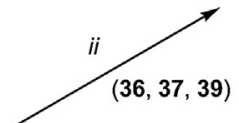

$\mathrm{H}_{2} \mathrm{~N}$

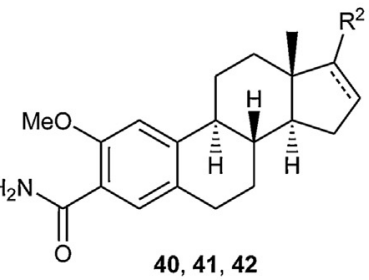

$40,41,42$

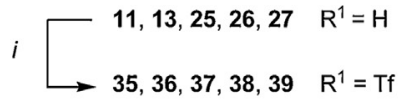

\begin{tabular}{r|l} 
& $\mathrm{R}^{2}$ \\
\hline $13,36,40$ & $-\mathrm{H}\left(\Delta^{16,17}\right)$ \\
$25,37,41,43,46$ & $=\mathrm{CH}_{2}$ \\
$27,39,42$ & $-\mathrm{H}$ \\
$11,29,35,45$ & $=\mathrm{O}$ \\
$26,38,44$ & $=\mathrm{CHCH}_{3}$
\end{tabular}<smiles></smiles>

iii<smiles>C1CCCC1</smiles>

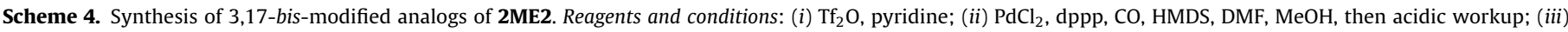
$\mathrm{Pd}(\mathrm{OAc})_{2}$, rac-BINAP, $\mathrm{Cs}_{2} \mathrm{CO}_{3}$, benzophenone imine, toluene, then $2 \mathrm{M} \mathrm{HCl}$, THF; (iv) $\mathrm{BrCN}, \mathrm{Et}_{2} \mathrm{O}, \mathrm{CH}_{2} \mathrm{Cl}_{2}$.

growth inhibition, but carboxamide analogs $\mathbf{4 0}$ and $\mathbf{4 1}$ were found to be 3- to 6-fold more potent in antiproliferative activity and 3to 5-fold more potent in antiangiogenic activity as compared with 2ME2. Moreover, all the carboxamides 40-42 possessed significantly better in vivo pharmacokinetic properties in mice than those of 2ME2.

Some 3,17-bis-modified analogs of 2ME2 containing sulfamate group(s) at position(s) 3 and/or 17 were also found to display potent antiproliferative effects [36-38]. These agents inhibit steroid sulfatase, carbonic anhydrase, cancer cell proliferation and angiogenesis. Replacement of OMe with an ethyl group on C-2 led to derivatives with increased potency.

It has been demonstrated that substitution of C-16 in 2ME2 with small alkyl groups leads to active derivatives [39]. The addition of steric and/or electronic bulk at this position was assumed to prevent or slow oxidation and/or conjugation at position 17 and consequently improve the antiangiogenic and antitumor effects observed for 2ME2 in vivo. For the transformations, 2ME2 was first

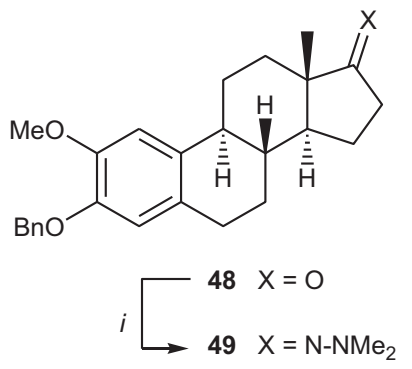

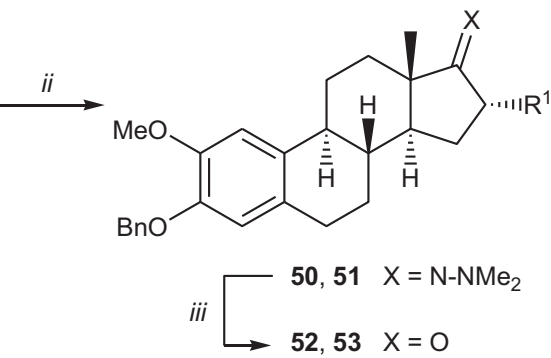

\begin{tabular}{l|l} 
& \multicolumn{1}{|c}{$\mathrm{R}^{1}$} \\
\hline $\mathbf{5 0 , 5 2 , 5 4 , 5 6}$ & $\mathrm{CH}_{3}$ \\
$\mathbf{5 1 , 5 3 , 5 5 , 5 7}$ & $\mathrm{CH}_{2} \mathrm{CH}_{3}$
\end{tabular}

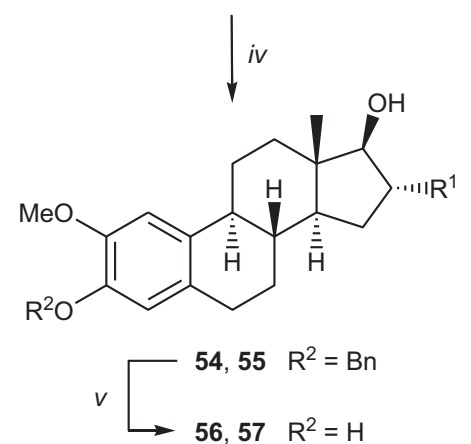

Scheme 5. Synthesis of 16-modified analogs of 2ME2. Reagents and conditions: (i) $\mathrm{NH}_{2} \mathrm{NMe}_{2}$, EtOH, DMF; (ii) $n \mathrm{BuLi}, \mathrm{THF}, \mathrm{R}^{1} \mathrm{I} ;(i i i) \mathrm{CuCl}_{2} \cdot 2 \mathrm{H}_{2} \mathrm{O} ; \mathrm{THF} / \mathrm{H}_{2} \mathrm{O} ;\left(\right.$ iv) $\mathrm{LiAlH}_{4} ; \mathrm{THF} ;(v)$ $\mathrm{H}_{2}, \mathrm{Pd} / \mathrm{C}$, EtOAc. 


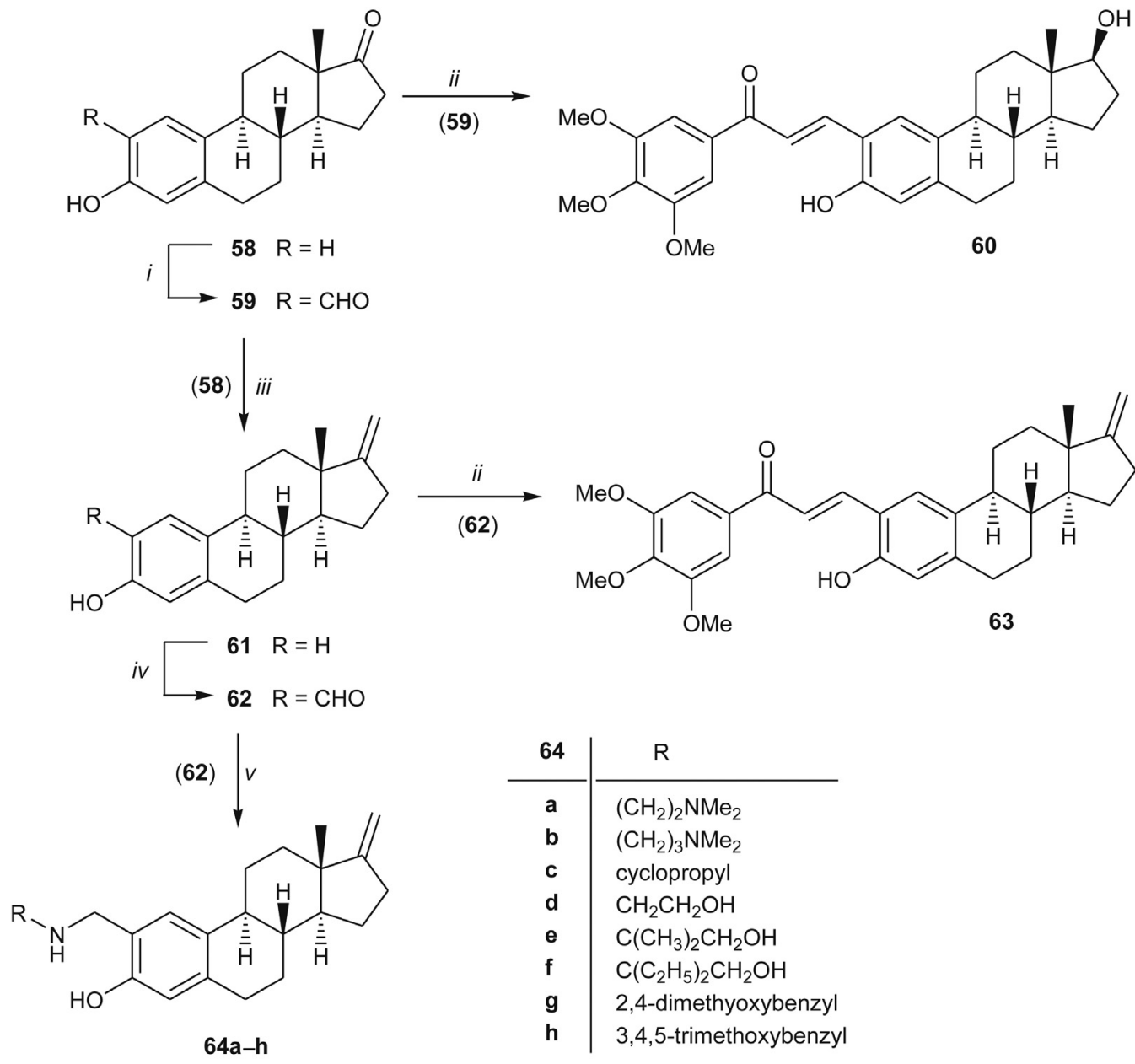

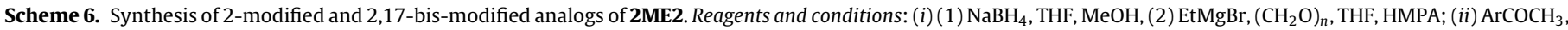
$\mathrm{MeOH}, \mathrm{KOH}$; (iii) $\mathrm{CH}_{3} \mathrm{P}^{+} \mathrm{Ph}_{3} \mathrm{I}^{-}$, NaH, DMSO; (iv) EtMgBr, $\left(\mathrm{CH}_{2} \mathrm{O}\right)_{n}$, THF, HMPA; (v) (1) $\mathrm{RNH}_{2}, \mathrm{Na}_{2} \mathrm{SO}_{4}, \mathrm{DMF},(2) \mathrm{NaBH}$, $\mathrm{MeOH}$.

protected as benzyl ether with $\mathrm{K}_{2} \mathrm{CO}_{3}$ /benzyl bromide in ethanol, and then oxidized to 3-O-benzyl-2-methoxyestrone (48) under Swern conditions [40]. The 16-substituted compounds $\mathbf{5 6}$ and $\mathbf{5 7}$ were prepared from $\mathbf{4 8}$ as starting material in multistep pathways (Scheme 5). Methyl and ethyl substitution were well tolerated for antiproliferative activity against MDA-MB-231 breast tumor cells, but 56 was found to be more estrogenic than 2 ME2.

Since steric and electronic factors at position 2 are prominent contributors to the cytotoxicity and the antitubulin activity of 2ME2 and its analogs [41], certain 2-substituted and 2,17-bis-modified analogs were prepared in an effort to improve the biological activity of 2ME2 (Scheme 6) [42]. Among the various synthesized compounds, some chalcone $(\mathbf{6 0}, \mathbf{6 3})$ and 2-alkylamino derivatives $(\mathbf{6 4 a}-\mathbf{h})$ were found to exhibit in vitro antiproliferative activities comparable with that of the parent analog against four human cancer cell lines [HCT-116 (colon), NCIH-460 (lung), U-251 (glioma), MB-435 (breast)].

The above-mentioned results led to further investigations being directed toward the synthesis of novel estrane-type antiproliferative agents. Thus, $15 \beta$-methylestrone-3-methyl ether (69), available from estrone (65), was demonstrated to inhibit the viability of MGC-803 (human gastric) cancer cells, similarly to doxorubicin (Scheme 7) [43]. The key step of the reaction sequence involved the stereoselective conjugate addition of a methyl group derived from $\mathrm{Me}_{3} \mathrm{Al}$ into $\mathbf{6 8}$ under $\mathrm{CuBr}$ catalysis. Zupko et al. have reported that a D-ring-expanded analog of estrone, compound 74, which can be synthesized in three steps from a
D-secoestrone-aldehyde 70, exerts a cytostatic effect on HeLa (human cervix epitheloid carcinoma) cells that is similar to that of cisplatin, but its selectivity toward noncancerous cells is significantly better than that of the reference compound [44]. Moreover, in vitro pharmacological studies confirmed modulation of the cell cycle progression through the promotion of several steps of apoptosis, and the lack of significant estrogenic activity [25]. DDihomologation by Barbier allylation - ring-closing metathesis, however, led to a derivative $\mathbf{7 7}$ with merely moderate antiproliferative activity [45].

\section{Synthesis and antiproliferative activity of androstane-derived compounds}

As compared with the estrane-derived semisynthetic molecules, for fewer examples are to be found in the literature as concerns the synthesis of simpler substituted androstane derivatives that exert cytostatic activity. Although dehydroepiandrosterone (78), the most abundant adrenal androgenic steroid in young adult humans, and its endogenous metabolites have been demonstrated to possess chemopreventive and antiproliferative effects [46,47], clarification of the exact mechanisms of their action is still required. Nevertheless, intensive searches for more potent and less androgenic androstane derivatives are ongoing. In this respect, the synthetic 3-ester $\mathbf{8 0}$ and 3-ether analog $\mathbf{8 1}$ of $\mathbf{7 8}$ have been found to exert promising antiproliferative activity toward a prostate cancer cell line (DU-145) associated with a better antiandrogenic effect 


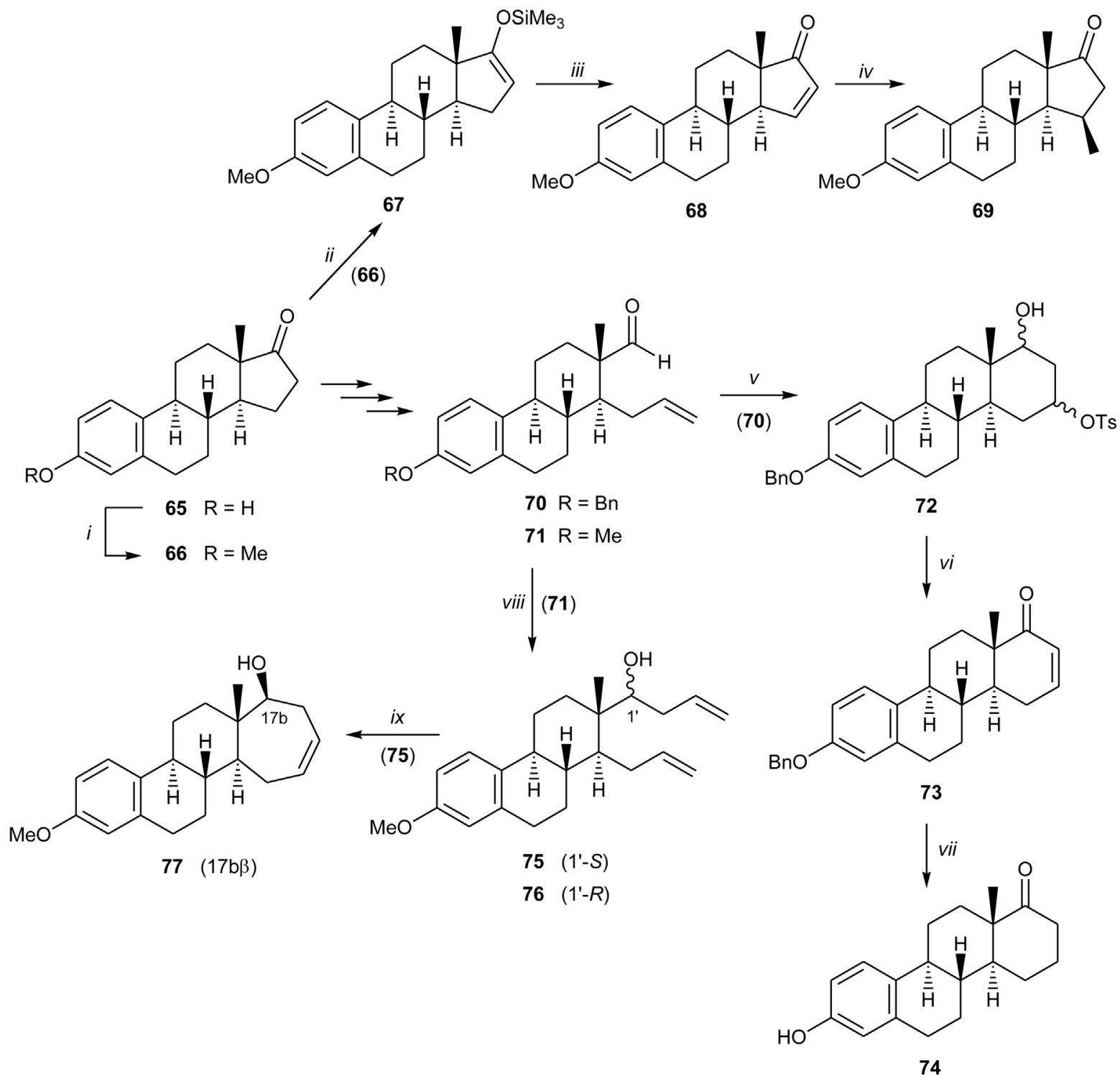

Scheme 7. Synthesis of modified estrone derivatives with antiproliferative activity. Reagents and conditions: (i) $\mathrm{Bu}_{4} \mathrm{~N}^{+} \mathrm{I}^{-}, \mathrm{MeI}, \mathrm{CH}_{2} \mathrm{Cl}$, $\mathrm{NaOH}$; (ii) (iPr) $)_{2} \mathrm{NH}, \mathrm{THF}, n \mathrm{BuLi}$, Et ${ }_{3} \mathrm{~N}$ TMSCl; (iii) $\mathrm{Pd}(\mathrm{OAc})_{2}, \mathrm{CH}_{3} \mathrm{CN}, \mathrm{CH}_{2} \mathrm{Cl}_{2}$; (iv) $\mathrm{Me}_{3} \mathrm{Al}, \mathrm{CuBr}$, TMSCl, THF; (v) p-TsOH, $\mathrm{CH}_{2} \mathrm{Cl}_{2}$; (vi) Jones reagent, acetone; (vii) $\mathrm{H}_{2}$, Pd/C, EtOAc; (viii) allyl bromide, $\mathrm{Zn}$, THF; (ix) $(\mathrm{NHC})\left(\mathrm{PCy}_{3}\right) \mathrm{Cl}_{2} \mathrm{Ru}=\mathrm{CHR}, \mathrm{CH}_{2} \mathrm{Cl}_{2}$.

than that of the reference control finasteride (Scheme 8) [48]. Djurendić et al. [49] investigated the cell growth-inhibitory effects of some D-homolactone derivatives of $\mathbf{7 8}$, and a 6 -nitro compound $\mathbf{8 4}$ proved to show high selectivity toward a prostate cancer cell line (PC-3) and low toxicity against normal fetal fibroblasts (MRC5).

Some $7 \alpha$-methyl-substituted $\Delta^{4}$-3-ones ( 88 and $\mathbf{9 4}$ ), synthesized in a highly stereoselective manner from their dienone precursors (87 and $\mathbf{9 3}$ ) by 1,6-conjugate addition, were reported to exhibit similar cytostatic activities on gastric cancer cell line MGC-803 to that of the reference doxorubicin (Scheme 9) [43].

\section{Synthesis and antiproliferative activity of hormone-derived heterocyclic compounds}

Besides the introduction of simple substituents onto the sterane skeleton, the construction of heterocyclic moieties either connected to or condensed with the original framework offers another possibility of obtaining analogs possessing antitumor activity. The most frequent synthetic modifications are performed on C-3, C-17 or $\mathrm{C}-20$, or on the carbon atoms adjacent to the already substituted C $-3, \mathrm{C}-17$ or C-20 due to the simple implementation. Substitution at other positions of the sterane skeleton has proved to be more difficult, necessitating several reaction steps, and is therefore rarely applied. Steroidal heterocycles containing various numbers of ring nitrogen atoms will be discussed bellow.

\subsection{Steroidal heterocycles containing one ring nitrogen atom}

Compounds that inhibit the enzyme aromatase have found applications in the treatment of advanced ER+ breast cancer. In recent years, highly potent and specific aromatase inhibitors have been developed [50,51]. A nonsteroidal inhibitor of aromatase, rogletimid (3-ethyl-3(4-pyridyl)piperidine-2,6-dione), contains a pyridine ring as an important constitutive element [52]. Accordingly steroidal 17-picolyl 96 and 17-picolinylidene 97 and 98 derivatives were synthesized from dehydroepiandrosterone (78), and their Oppenauer oxidation led to the corresponding $\Delta^{4}$-3ketosteroids 100 and $\mathbf{1 0 3}$ (Scheme 10), which similarly proved to be 

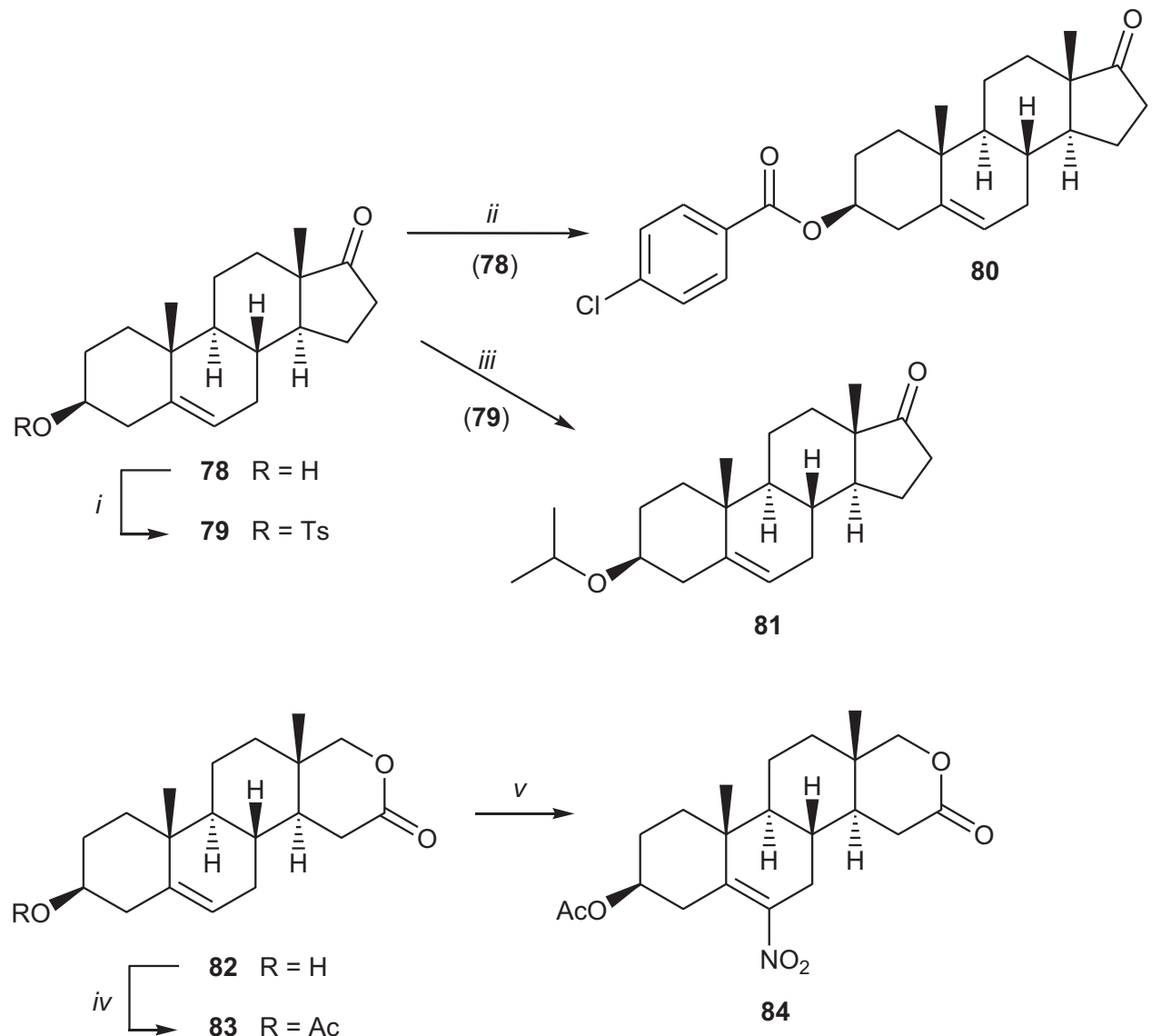

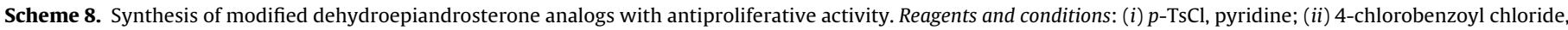
pyridine; (iii) $i \mathrm{PrOH}$; (iv) $\mathrm{Ac}_{2} \mathrm{O}$; pyridine; $(v) \mathrm{HNO}_{3}, \mathrm{NaNO}_{2}, \mathrm{Et}_{2} \mathrm{O}$.

aromatase inhibitors [53]. In investigations of the relation between the aromatase inhibitory effect and the antitumor activity, therefore, some modified derivatives were tested on three tumor cell lines: MCF-7 (ER+ human breast adenocarcinoma), MDA-MB-231 (ER- human breast adenocarcinoma) and PC3 (prostate cancer). Both the $N$-oxides 99 and 104 prepared from 97 and 103, respectively, by oxidation with $m$-chloroperoxybenzoic acid (MCPBA), and also the starting material 96 were found to exert strong antiproliferative activity against $\mathrm{PC} 3$, with $\mathrm{IC}_{50}$ values in the range $0.55-10 \mu \mathrm{M}$, while the $4 \beta, 5 \beta$-epoxide $\mathbf{1 0 2}$ obtained from $\mathbf{1 0 0}$ on reaction with $\mathrm{H}_{2} \mathrm{O}_{2}$ in alkaline medium displayed a marked cell growth-inhibitory effect against MDA-MB-231 [54]. It additionally emerged that the 16-keto analogs of $\mathbf{9 7}$ and 98 [55,56] effectively inhibited the proliferation of HeLa, FemX (human melanoma) and K562 (human myelogenous leukemia) cells [53].

Besides picolyl derivatives, various steroidal isoxazolidines and isoxazoles were synthesized and investigated for their antiproliferative activity. The thermally induced intramolecular 1,3-dipolar cycloadditions of a D-secopregnene aldehyde (105) (obtained from pregnadienolone acetate [57]) with $N$-substituted hydroxylamines furnished $\mathrm{N}$-functionalized isoxazolidines $\mathbf{1 0 7}$ diastereoselectively, via the corresponding alkenyl nitrones $\mathbf{1 0 6}$ (Scheme 11). When the cytostatic effects of the 3-deacetylated compounds $\mathbf{1 0 8}$ were tested in vitro, the $N$-benzyl-substituted derivative $\left(\mathrm{R}^{2}=\mathrm{Bn}\right)$ displayed the highest activity on HeLa cells, with an $\mathrm{IC}_{50}$ value comparable to that of the reference cisplatin [58].

Steroidal $17 \alpha$-isoxazoles in the estrane series were also prepared by 1,3-dipolar cycloaddition (Scheme 12). The Cul-catalyzed regioselective ring closures of different aryl nitrile oxides with mestranol (109) afforded the exo-heterocyclic products $\mathbf{1 1 0}$ in good to excellent yields $[59,60]$. These novel isoxazolyl derivatives, which lack an estrogenic effect [61], were subjected to in vitro pharmacological studies in order to investigate their antiproliferative effects on three malignant human gynecological cell lines. The fluorinated analog $110(\mathrm{R}=p-\mathrm{F})$ and the $p$-nitro-substituted derivative $110\left(\mathrm{R}=p-\mathrm{NO}_{2}\right)$ proved to be the most promising compounds as concerns cell growth inhibition.

\subsection{Steroidal heterocycles containing two ring nitrogen atoms}

Investigations of the antiproliferative activities of this type of compounds have mainly focused on derivatives containing a pyrazoline moiety. An efficient and facile synthesis of $17 \beta$-pyrazolinyl derivates was reported by Banday et al. [62]. The reaction sequence involved the conversion of pregnenolone (111) to benzylidene derivatives $\mathbf{1 1 2}$ with (substituted) benzaldehyde(s), and the subsequent ring closures of $\mathbf{1 1 2}$ with hydrazine in the presence of acetic acid (Scheme 13). Although the newly formed stereogenic center at $C-5^{\prime}$ can allow the formation of two epimers (113 and 114), the products were tested as the unseparated mixtures on seven human cancer cell lines [HT-29, HCT-15 (colon), 502,713 (colon), HOP-62, A-549 (lung), MCF-7 (breast) and SF-259 (CNS)]. The IC 50 values of the diastereomeric products $(\mathbf{1 1 3}+\mathbf{1 1 4})$ indicated that some of the compounds $\left(\mathrm{R}=m-\mathrm{F}, p-\mathrm{F}, o-\mathrm{CH}_{3}, m-\mathrm{CH}_{3}\right.$ and $p$-OMe) exerted significant cytotoxic activity, especially against the colon cell lines. Moreover, the cytotoxicity of the analogs for certain cancer cell lines varied more than 100-fold on change of the position of a given substituent on the aromatic ring (e.g. $\mathrm{R}=o-\mathrm{OMe} v s . \mathrm{R}=p$ OMe). Following the synthetic route indicated above, Iványi et al. prepared further pyrazolinyl derivatives, which could be separated, 
<smiles>C[C@@]12CCC3=CC(=O)CC[C@@H]3CC[C@H]1[C@@H](O)CC2</smiles>

85

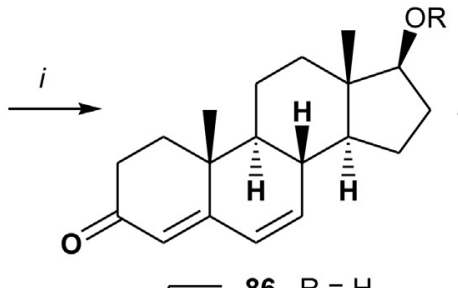

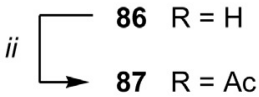

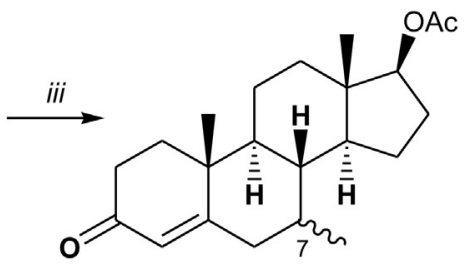

$88(7 \alpha): 89(7 \beta)=5: 1$<smiles>C[C@]12CC[C@@H]3[C@H](CC[C@H]3O)[C@@]1(C)CC[C@H]2O</smiles>

90

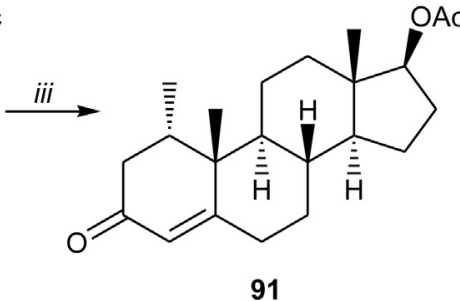

91

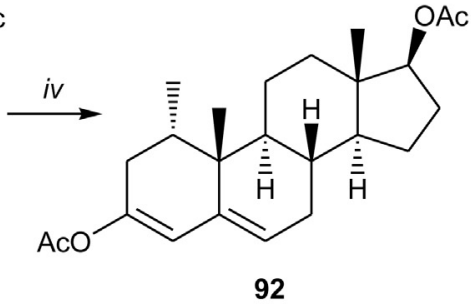

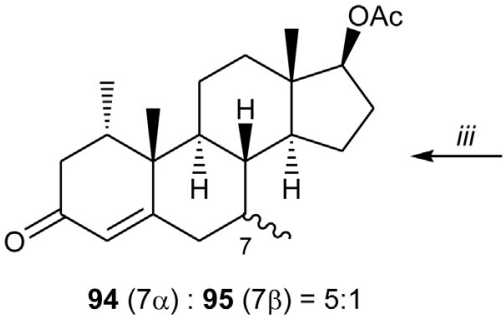

iii<smiles>CC1([V])CCCCC1</smiles>
$v$<smiles>CC(=O)O[C@H]1CC[C@H]2[C@@H]3C=CC4=CC(=O)C[C@H](C)[C@]4(C)[C@H]3CC[C@]12C</smiles>

93

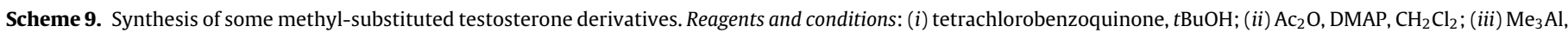
$\mathrm{CuBr}, \mathrm{TMSCl}$, THF; (iv) $\mathrm{Ac}_{2} \mathrm{O}, \mathrm{AcCl} ;(v)$ NBS, $\mathrm{LiBr}, \mathrm{Li}_{2} \mathrm{CO}_{3}$.

but only in their acetylated forms (115 and 116) [63]. The deacetylated isomers 113 and $\mathbf{1 1 4}$ were tested separately on four cancer cell lines: HeLa (cervix), MCF7 (breast), A2780 (ovarian) and A431 (skin), but their antiproliferative potencies were not comparable with those of the reference cisplatin. However, it should be noted that substantial differences were found in the in vitro results on the diastereomeric pairs: the $5^{\prime} S$ epimers $\mathbf{1 1 4}$ were more potent than their $5^{\prime} R$ counterparts 113.

As regards the six-membered $N, N$-heterocycles, Poirier et al. $[64,65]$ reported the synthesis of a large set of $2 \beta$-( $N$-substituted piperazino)- $5 \alpha$-androstane derivatives and several compounds were found to inhibit the proliferation of HL-60 human leukemia cells.

Besides simple heteroring substitution, another possibility for the design of cytostatic steroidal agents is the construction of molecules structurally similar to natural steroid alkaloids. Plants are among the most varied and promising sources of new anticancer drugs, as they contain compounds which are produced by specific enzyme-catalyzed processes that differ significantly from those in animals and humans. Some of these alkaloid analogs are known to have cytotoxic properties [66] or to act as chemosensitizers in multidrug resistance [67]; consequently, structurally related compounds may have similar or even improved biological activity. In this respect, an efficient approach has been reported to novel androstene-fused arylpyrazolines that can be regarded as synthetic solanidine analogs, and these compounds were tested for their antiproliferative activities [26,68]. The highly diastereoselective Lewis acid-induced intramolecular 1,3-dipolar cycloadditions of alkenylphenylhydrazones $\mathbf{1 1 7}$ obtained from D-secopregnene aldehyde 105 resulted in D-ring-fused products 118 in good to excellent yields (Scheme 14). The ability of phenylhydrazones $\mathbf{1 1 7}$ to undergo cyclization was found to be affected significantly by the electronic features of the substituents $\left(\mathrm{R}^{1}\right)$ on the aromatic moiety. Both the experimental findings and theoretical calculations indicated that the cycloadditions follow a stepwise rather than a pure concerted mechanism. The antiproliferative activities of the pyrazoline derivatives 118 and 119 were tested in vitro on three malignant human cell lines (HeLa, MCF7 and A431): the microculture tetrazolium assay (MTT) revealed that several compounds exerted marked cell growth-inhibitory effects. The highest cytostatic activities, displayed by the $p$-methoxyphenylpyrazoline derivative $\mathbf{1 1 9}$ $\left(\mathrm{R}^{1}=p\right.$-OMe), were better than those of cisplatin. Moreover, this compound inhibited the proliferation of normal human fibroblast cells (MRC-5) at a one order of magnitude higher concentration $\left(\mathrm{IC}_{50}=17.01 \mu \mathrm{M}\right)$ than for HL-60 leukemia cells $\left(\mathrm{IC}_{50}=1.27 \mu \mathrm{M}\right)$, reflecting its efficiently selective cytotoxic activity [69]. Further pharmacological studies indicated that $\mathbf{1 1 9}\left(\mathrm{R}^{1}=p\right.$-OMe $)$ promoted a marked disturbance in the cell cycle, and induced the manifestation of the markers of early apoptosis and secondary necrosis, which was in part a consequence of its inhibitory effect on the activity of ribonucleotide reductase.

\subsection{Steroidal heterocycles containing three ring nitrogen atoms}

Among the heterocyclic systems, triazole often demonstrates some special activity when it is introduced into biological active compounds [70-72]. Moreover, the basicity and hydrophilicity of this moiety might alter the pharmacological function of a steroid. With regard to these facts, therefore, a number of steroidal triazoles have been synthesized during the past few years, through 


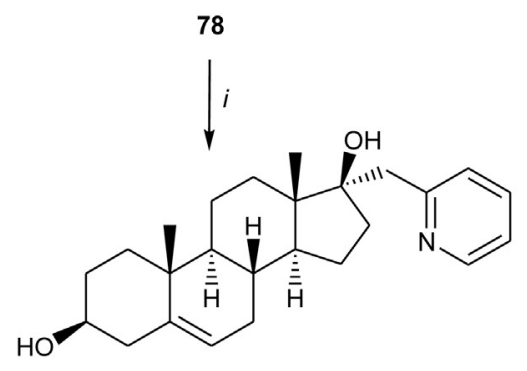<smiles>C[C@]12CCC(=O)C=C1CC[C@H]1[C@@H]2CC[C@]2(C)[C@H]1CC[C@@]2(O)c1ccccn1</smiles>

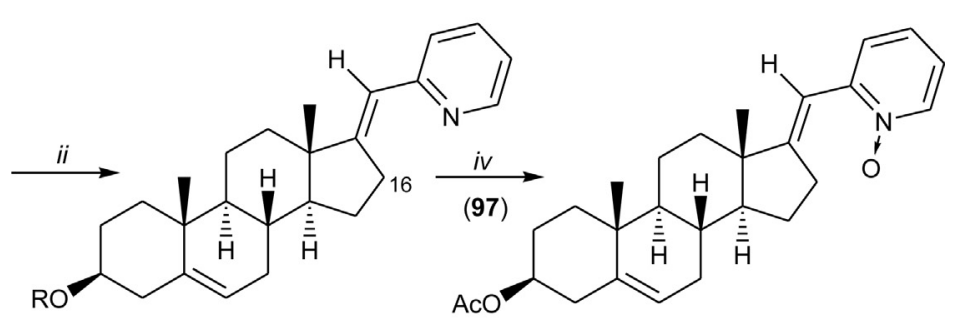
iii

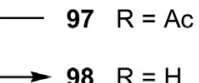

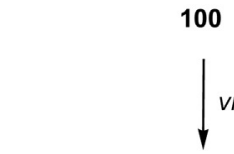

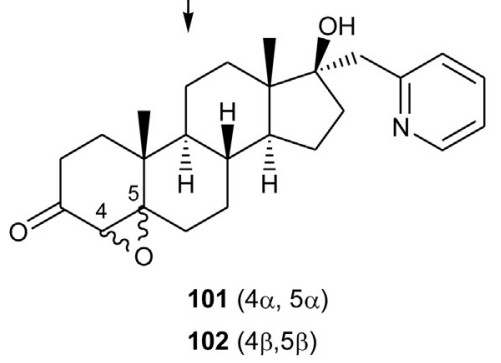

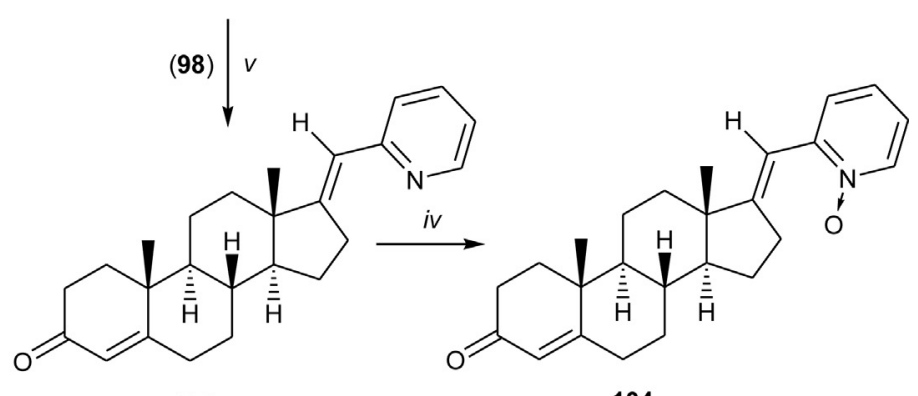

103

104

Scheme 10. Synthesis of some picolyl-substituted derivatives. Reagents and conditions: (i) $\alpha-\mathrm{PyCH}_{2} \mathrm{Li}, \mathrm{THF}$; (ii) $\mathrm{Ac}_{2} \mathrm{O}$; (iii) $\mathrm{KOH}, \mathrm{MeOH}$; (iv) $\mathrm{MCPBA}, \mathrm{CH}_{2} \mathrm{Cl}_{2}, \mathrm{NaHCO}{ }_{3}$; (v) $\mathrm{Al}(t \mathrm{BuO})_{3}$, cyclohexanone; (vi) $\mathrm{H}_{2} \mathrm{O}_{2}, \mathrm{NaOH}, \mathrm{MeOH}$.

a click chemistry approach. The synthetic routes involve the introduction of an azido group into any position of the sterane framework and the subsequent ring closure of the steroidal azide with a terminal acetylene in the presence of a $\mathrm{Cu}(\mathrm{I})$ source. $\mathrm{Cu}(\mathrm{I})$ catalyzed azide-alkyne cycloaddition (CuAAC) is convenient for the regioselective construction of 1,4-disubstituted triazoles in which the heterocycle is attached directly to the steroid nucleus through a nitrogen atom, or these two moieties are connected to each other through a linker. The reaction has further advantageous benefits, such as high yields of the desired products, tolerability to a variety of common parameters (functional groups, solvents, $\mathrm{pH}$ and temperature), the lack of by-products and insensitivity to the steric and electronic properties of the reactants [73-75].
The simplest procedures for the formation of steroidal azides are either the modification of extant functional groups (C-3, C17 or $(-20)$ in the original hormone analog or substitution at adjacent positions (C-2, C-16 or C-21). Thus, Bandy et al. [76] recently reported a facile synthesis of 21-triazolyl derivatives of pregnenolone by using an in situ one-pot CuAAC (Scheme 15). In this case the triazolyl moiety is attached to the steroid nucleus through a methylene ketone linkage. The synthesis started from pregnenolone (111), which was treated with $\mathrm{Br}_{2} / \mathrm{MeOH}$ in the dark to furnish 21-bromopregnenolone (120) in good yield. The in situ two-step conversion of $\mathbf{1 2 0}$ in the presence of $\mathrm{NaN}_{3}, \mathrm{CuSO}_{4}$, sodium ascorbate and the appropriate alkyne in a 1:1 mixture of tert-butanol and water resulted in 21-triazolylpregnenolone derivatives 121a-g. These compounds were screened in vitro for

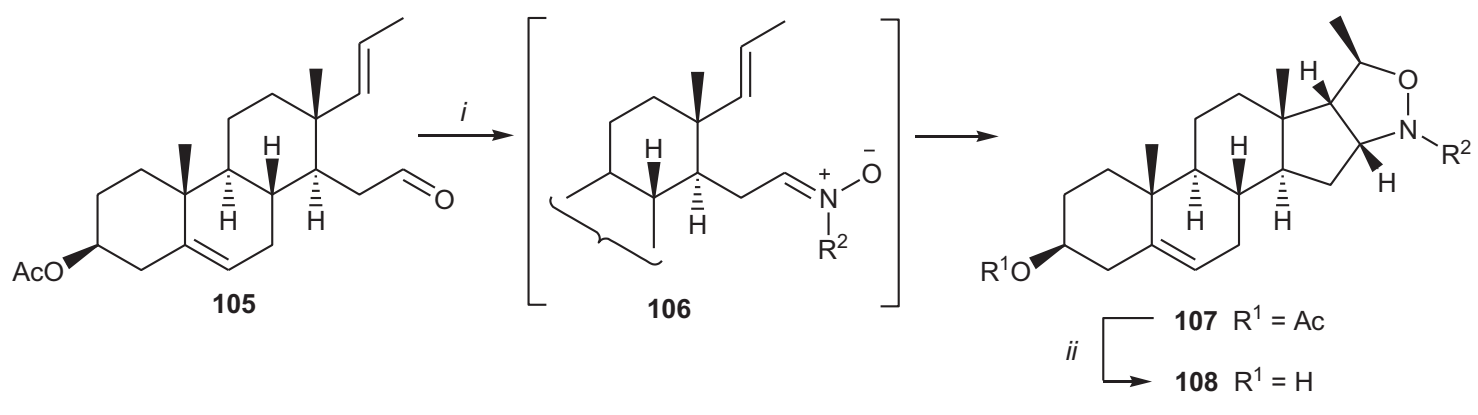

$\mathrm{R}^{2}=\mathrm{H}, \mathrm{Me}, \mathrm{Pr}, \mathrm{Ph}, \mathrm{Bn}$ 


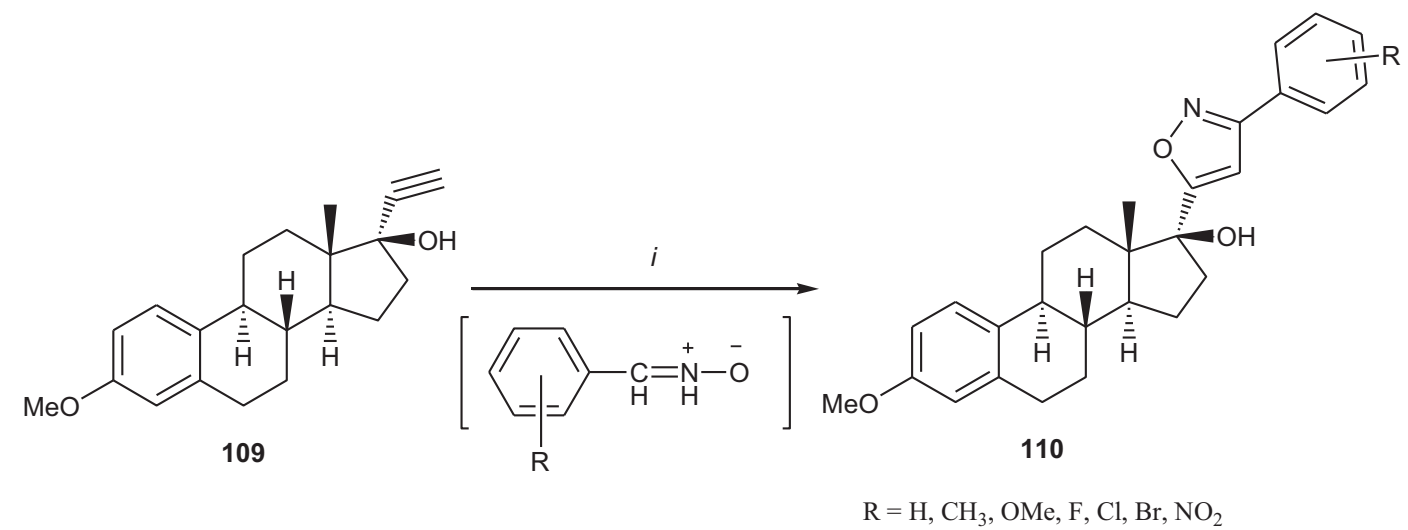

Scheme 12. Synthesis of $17 \alpha$-isoxazoles by $\mathrm{Cu}(\mathrm{I})$-catalyzed 1,3-dipolar cycloaddition. Reagents and conditions: (i) $\mathrm{CuI}, \mathrm{Ph}{ }_{3} \mathrm{P}, \mathrm{DIPEA}$, toluene.

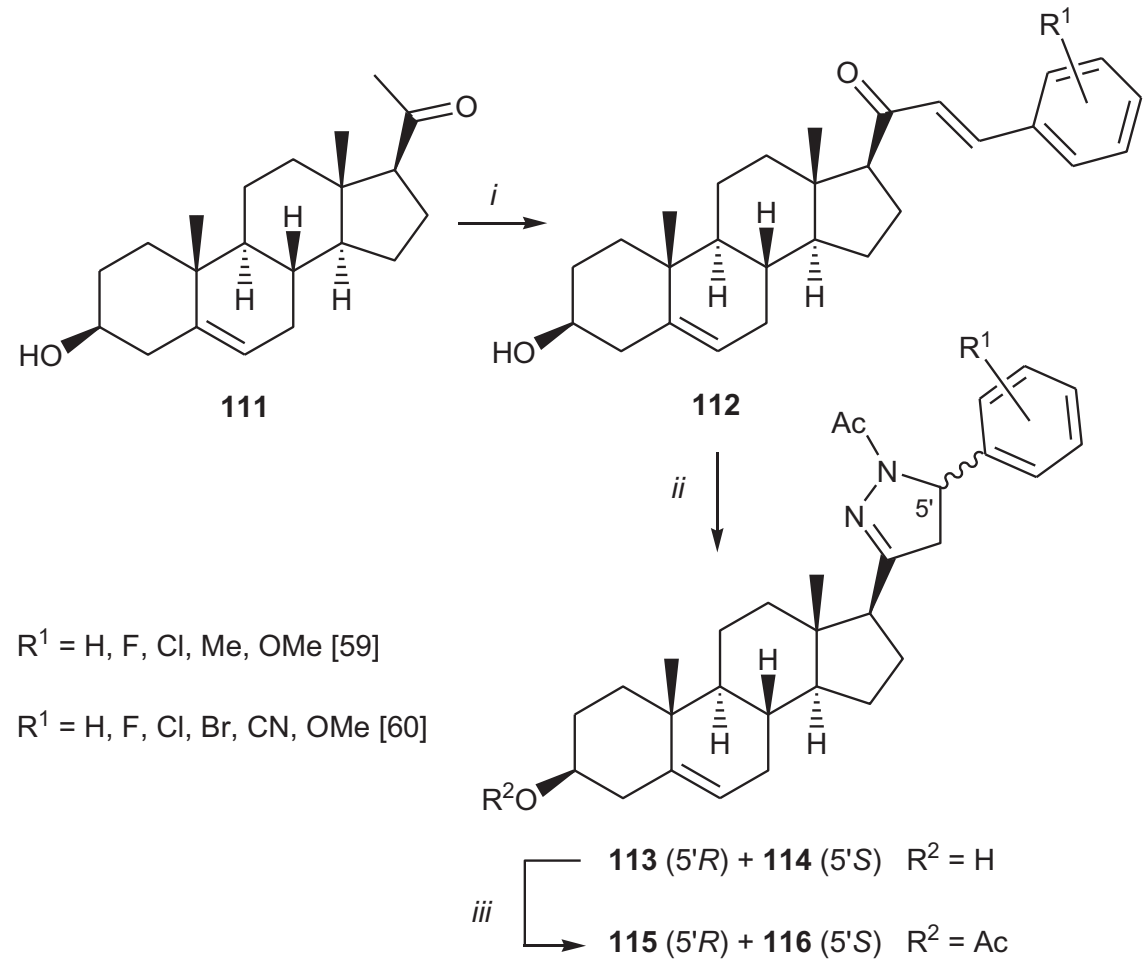

Scheme 13. Synthesis of 17-exo-pyrazolinyl derivatives. Reagents and conditions: (i) ( $\mathrm{R}^{1}$ )benzaldehyde, EtOH, $\mathrm{NaOH}$; (ii) AcOH, hydrazine hydrate; (iii) Ac ${ }_{2} \mathrm{O}$, pyridine.<smiles>C/C=C/[C@]1(C)CCC(C)CC1CC=O</smiles>

105

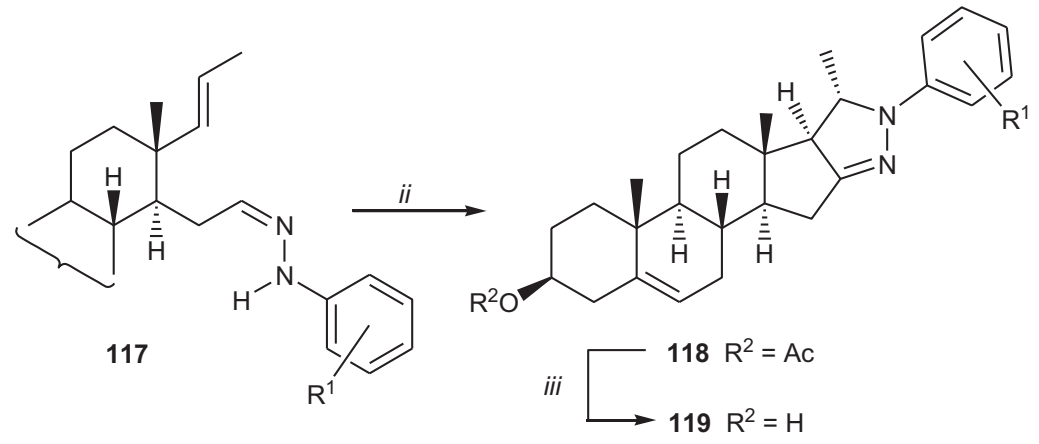

$\mathrm{R}^{1}=\mathrm{H}, \mathrm{CH}_{3}, \mathrm{OMe}, \mathrm{Cl}, \mathrm{COOH}, \mathrm{CF}_{3}, \mathrm{OCF}_{3}, \mathrm{NO}_{2}, \mathrm{CN}$ 


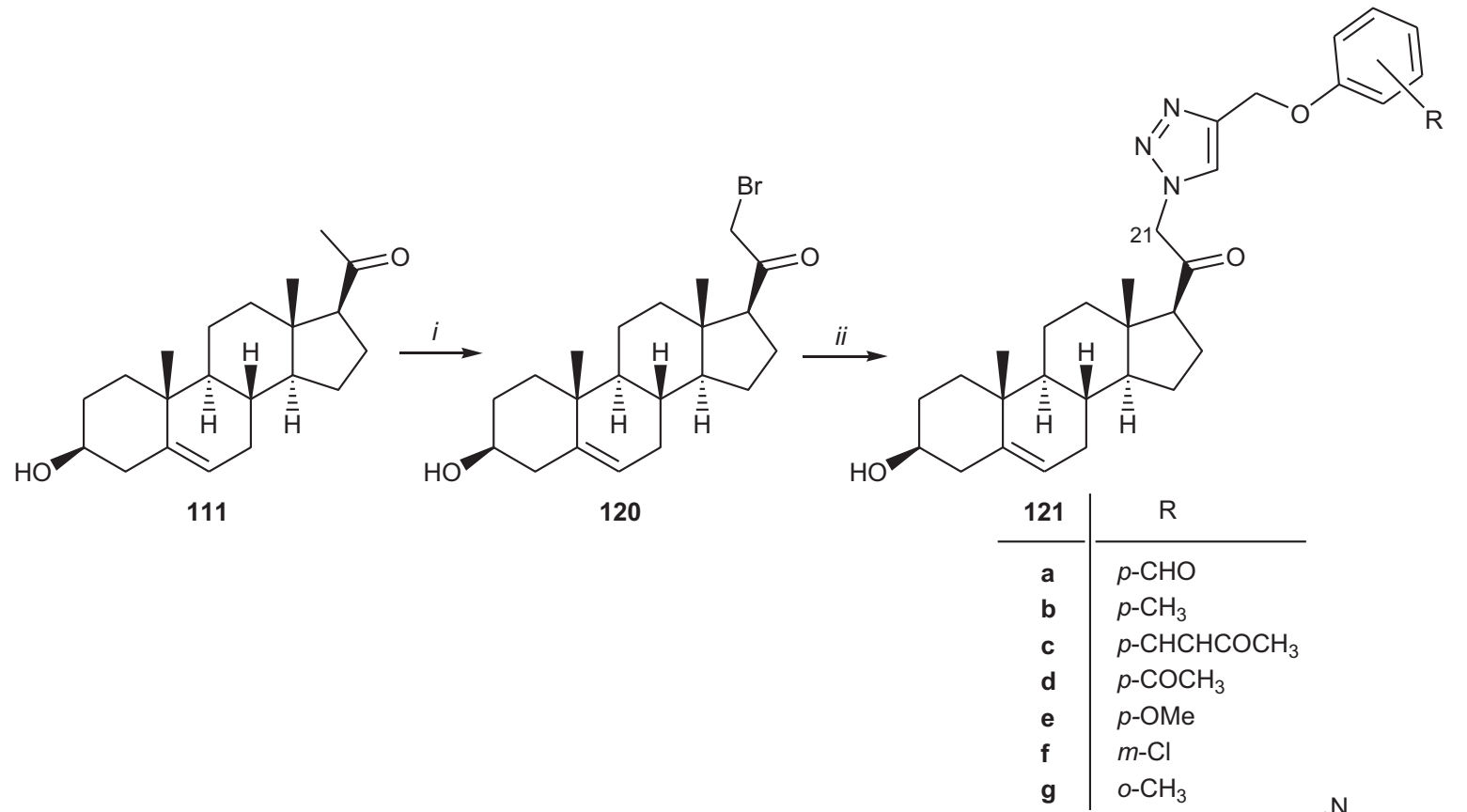

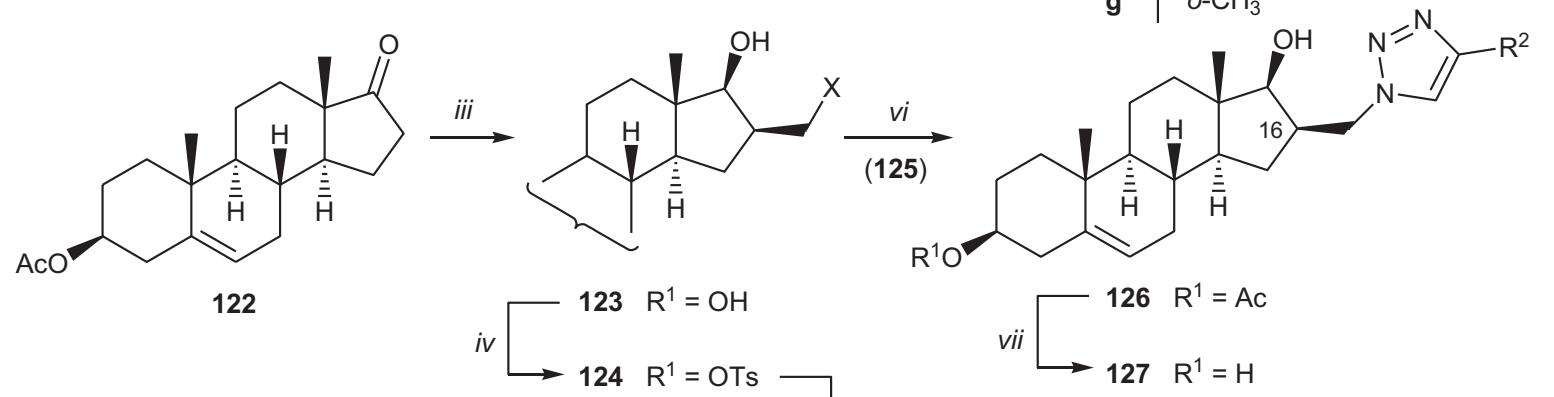
$125 \mathrm{R}^{1}=\mathrm{N}_{3} \longleftarrow v \quad \mathrm{R}^{2}=$ aryl, pyridyl, cyclopropyl

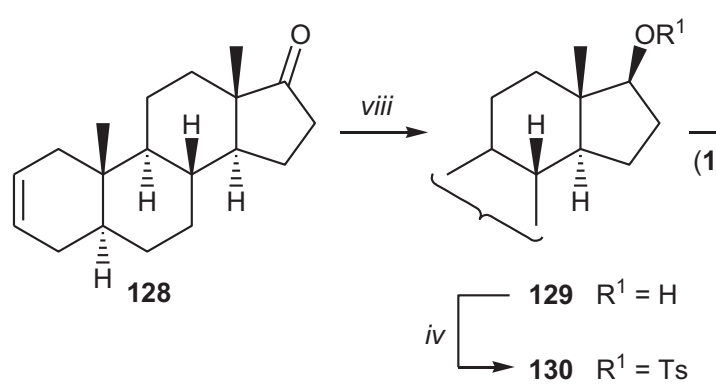

$\overrightarrow{(130)}$<smiles>C[C@H]1CC[C@@H]2[C@H](N)CC[C@]12C</smiles>

131

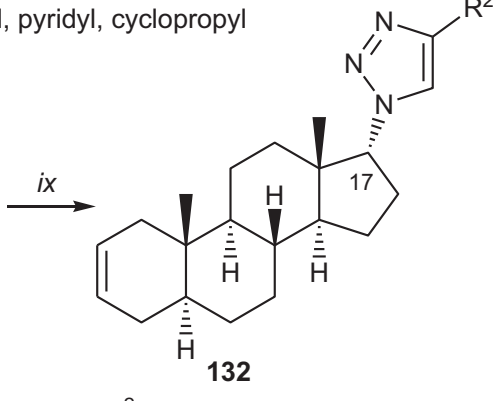

$\mathrm{R}^{2}=$ aryl, cycloalkyl

Scheme 15. Construction of triazolyl moieties at the site of an already existing functional group (C-17) or in nearby (C-16 or C-21) positions. Reagents and conditions: (i) $\mathrm{HBr}, \mathrm{Br}_{2}, \mathrm{MeOH}$; (ii) $\mathrm{NaN}_{3}, \mathrm{CuSO}_{4} \cdot 5 \mathrm{H}_{2} \mathrm{O}$, Na ascorbate, $t \mathrm{BuOH}, \mathrm{H}_{2} \mathrm{O}, \mathrm{HC}=\mathrm{CCH}_{2} \mathrm{OC}_{6} \mathrm{H}_{4} \mathrm{R}$; (iii) (1) ethyl formate, NaOMe, toluene, (2) $\mathrm{Ac}_{2} \mathrm{O}$, pyridine, (3) KBH , EtOH; (iv) TsCl,

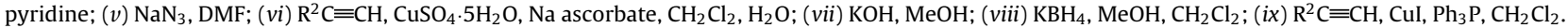

their activity against seven human cancer cell lines, i.e. DU-145, PC3 (prostate), SF-295 (CNS), HCT-15, 502713 (colon), HEP-2 (liver) and A-549 (lung), using the sulforhodamine B assay. The $\mathrm{IC}_{50}$ values revealed that $121 \mathrm{e}(\mathrm{R}=\mathrm{p}$-OMe $)$ exerted significant cytotoxicity against the PC-3, HCT-15 and 502713 cell lines, while the other derivatives were found to be effective against all these diverse cancer cell lines.

Kádár et al. [77] recently prepared 1,2,3-triazolyl derivatives in the androstane series in which the heterocycle is connected to $\mathrm{C}-16$ of the sterane framework through a methylene group. The Claisen condensation of $3 \beta$-acetoxyandrost-5-en17-one (122) with ethyl formate in the presence of $\mathrm{NaOMe}$ and the subsequent acetylation/reduction sequence led to three $3 \beta$-acetoxy-16-hydroxymethyl-17-diols, from which the
16 $\beta$-hydroxymethyl-17 $\beta$-hydroxy isomer 123 was separated (Scheme 15). After conversion of the primary hydroxyl group of 123 to $p$-toluenesulfonate derivative 124 , nucleophilic substitution with $\mathrm{NaN}_{3}$ was carried out to furnish the corresponding azide 125. Various aryl, heteroaryl and cycloalkyl-substituted triazoles $\mathbf{1 2 6}$ were then synthesized by the CuACC of $\mathbf{1 2 5}$ with various terminal alkynes, $\mathrm{CuSO}_{4} \cdot 5 \mathrm{H}_{2} \mathrm{O}$ serving as $\mathrm{Cu}(\mathrm{I})$ source in reductive medium. For the cyclizations, a mixture of dichloromethane as solvent and water as co-solvent was employed to eliminate the need for ligands and to simplify the reaction protocol [78]. The antiproliferative activities of the deacetylated analogs (127) were determined in vitro with the MTT assay on three gynecological cell lines (HeLa, MCF-7 and A2780). Compound 127, containing a 3-methylphenyl group on the triazolyl moiety, was found to exert a marked cell 
<smiles>CC[C@@]1(C)C(=O)C=C[C@@H]2c3ccc(OC)cc3CC[C@H]21</smiles>

68<smiles>CC[C@@]1(C)CC[C@@H](N)[C@@H]2c3ccc(OC)cc3CC[C@H]21</smiles>

133<smiles>COc1ccc2c(c1)CC[C@H]1C(=O)CC[C@@H](n3cc(-c4ccccc4)nn3)[C@H]21</smiles>

134

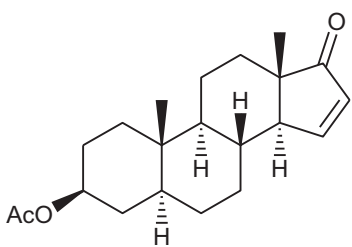

135

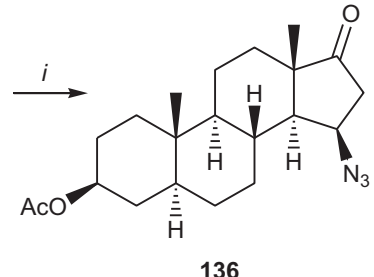

136

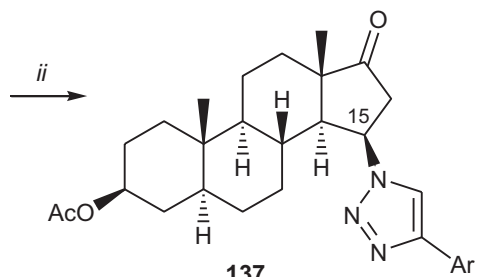

137

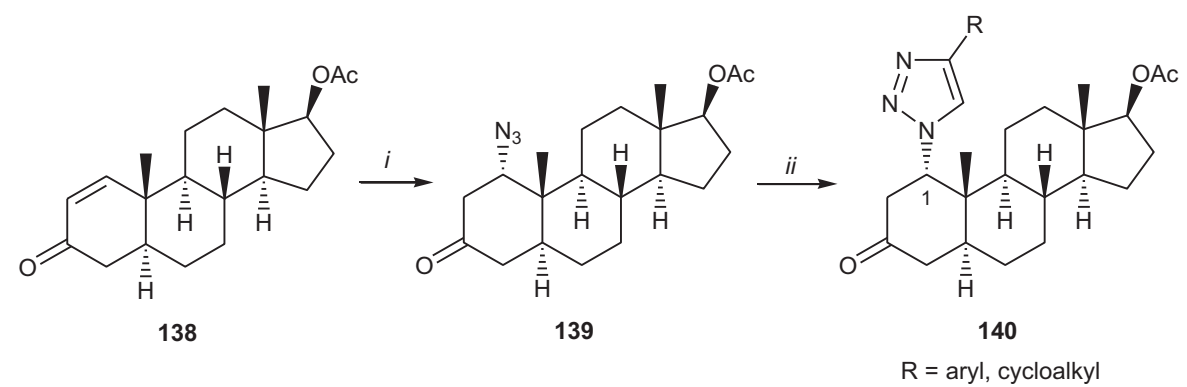

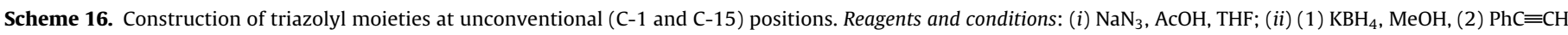
(for 134), $\mathrm{ArC} \equiv \mathrm{CH}$ (for 137) or $\mathrm{RC} \equiv \mathrm{CH}$ (for 140), $\mathrm{CuI}, \mathrm{Ph}_{3} \mathrm{P}$, DIPEA, (3) Jones reagent, acetone.

growth-inhibitory effect on A2780 cells, while the 2-pyridyl derivative proved effective on HeLa cells.

The preparation of novel $17 \alpha$-triazoles in which the heterocycle is attached directly to ring $\mathrm{D}$ of the sterane core has also been reported recently [24]. For the CuAACs, steroidal $17 \alpha$-azide 131, readily available from $5 \alpha$-androst-2-en-17-one (128) in a three-step pathway, was used as starting material (Scheme 15). Stereoselective reduction of the 17-keto group, leading to $\mathbf{1 2 9}$, was followed by tosylation to give $\mathbf{1 3 0}$, which then underwent facile $\mathrm{S}_{\mathrm{N}} 2$ substitution with $\mathrm{NaN}_{3}$ to furnish the corresponding $17 \alpha$-azido compound 131. The ring closures of 131 with different terminal acetylenes were carried out in refluxing dichloromethane with $\mathrm{CuI}$ as catalyst in the presence of $\mathrm{Ph}_{3} \mathrm{P}$. Although determination of the affinities for the hormonal receptors did not fall within the scope of the work, in the absence of a keto functional group at position $\mathrm{C}-3$, the newly prepared triazolyl derivatives were considered not to possess an androgenic effect. The in vitro pharmacological tests indicated that 132, containing a cyclopropyl group $\left(R^{2}\right)$ on its heterocycle, possessed the highest activity, causing 82-98\% growth inhibition on all malignant cell lines (HeLa, MCF7 and A431) at $30 \mu \mathrm{M}$, and was therefore comparable to the reference compound cisplatin. Interestingly, the similar transformations in the estrane series led to $17 \alpha$-triazoles that generally exhibited lower pharmacological activities.

Further triazolyl derivatives were synthesized in both the estrane and the androstane series, in which the triazolyl moiety was situated at the unconventional C-15 position [79]. First, an azido group was introduced stereoselectively onto position $15 \beta$ of sterane skeleton of the unsaturated ketones $\mathbf{6 8}$ and 135 by the 1,4-Michael addition of azoimide [80], generated in situ from $\mathrm{NaN}_{3}$ and acetic acid, to afford azidoketones 133 and 136 in good yields (Scheme 16). After subsequent reduction of the 17-keto group in order to avoid elimination, the resultant steroidal cis-azidoalcohols were reacted with different terminal alkynes. The best conversions were observed on the use of a catalytic amount of $\mathrm{CuI}$ with $\mathrm{Ph}_{3} \mathrm{P}$ as stabilizing ligand and excess $\mathrm{N}, \mathrm{N}$-diisopropyl ethylamine (DIPEA) as amine base in refluxing toluene. The following Jones oxidation afforded the corresponding 17-keto $15 \beta$-triazolyl derivatives 134 and 137 in both the estrane and the androstane series. The antiproliferative activities of the synthesized compounds were determined by using three malignant adherent cell lines (HeLa, MCF7 and A431) in the MTT assay, in comparison with cisplatin as positive control. $15 \beta$-Triazolylestrone methyl ether (133) and its 17-hydroxy analog exhibited marked antiproliferative effects against A431 cells, while the $5 \alpha$-androstane counterpart (137) exerted similar or higher activities on HeLa and MCF7 cells than these of cisplatin. Since substantial differences were not detected between the $\mathrm{IC}_{50}$ values of the different aryl-substituted derivatives of 137, it was concluded that the substituent on the triazolyl ring does not have a crucial impact on the anticancer capacities of this skeleton. Further biochemical and morphological results indicated that the initiation of apoptosis predominated in the antiproliferative action of the tested compounds.

After a systematic study of D-ring-substituted triazolyl compounds, a number of analogous derivatives were prepared in which the triazoles were connected to ring A [81]. Starting from unsaturated ketone $\mathbf{1 3 8}$, an azido group was introduced onto position 1 of the sterane skeleton by Michael addition, which resulted stereoselectively in the $1 \alpha$-azido isomer 139 due to the steric bulk of the neighboring angular methyl group. $1 \alpha$-Triazolyl-17-oxo derivatives 140 were obtained in a rather roundabout way following the reduction-CuAAC-oxidation sequence. These derivatives exerted outstanding cytotoxic activity on HeLa cells, characterized by $\mathrm{IC}_{50}$ values between 1 and $2 \mu \mathrm{M}$, i.e. one order of magnitude lower than 
that of the reference cisplatin. On the other hand, the cell lines MCF7 and A2780 seemed to be much less sensitive to $\mathbf{1 4 0}$ than to cisplatin.

\section{Summary}

The routes available to date for the synthesis of sex hormone-derived steroidal compounds that display marked cell growth-inhibitory effects on one or more cancer cell lines of diverse origins have been discussed. The results achieved so far demonstrate that the introduction of either simple substituents or heterocyclic moieties may alter the biological activities of the parent compounds significantly, and the application of suitable modifications can eliminate the undesirable hormonal properties. Thus, both structure-based drug design and a more random search for effective derivatives appear to deserve attention in the quest for novel steroidal anticancer agents.

\section{Acknowledgments}

This work was supported financially by the New Hungary Development Plan (TÁMOP TÁMOP-4.2.2.A-11/1/KONV-2012-0047) and the Hungarian Scientific Research Fund (K 101659). The project "TÁMOP 4.2.1/B-09/1/KONV-2010-0005 - Creating the Center of Excellence at the University of Szeged" is supported by the European Union and co-financed by the European Regional Fund.

\section{References}

[1] G. Guerriero, Vertebrate sex steroid receptors: evolution, ligands, and neurodistribution, Annals of the New York Academy of Sciences 1163 (2009) 154-168.

[2] M.K. Thakur, V. Paramanik, Role of steroid hormone coregulators in health and disease, Hormone Research 71 (2009) 194-200.

[3] G.M. Anstead, K.E. Carlson, J.A. Katzenellenbogen, The estradiol pharmacophore: ligand structure-estrogen receptor binding affinity relationships and a model for the receptor binding site, Steroids 62 (1997) 268-303.

[4] A.G. Fragkaki, Y.S. Angelis, M. Koupparis, A. Tsantili-Kakoulidou, G. Kokotos, C. Georgakopoulos, Structural characteristics of anabolic androgenic steroids contributing to binding to the androgen receptor and to their anabolic and androgenic activities. Applied modifications in the steroidal structure, Steroids 74 (2009) 172-197.

[5] A. Hillisch, J. von Langen, B. Menzenbach, P. Droescher, G. Kaufmann, B. Schneider, W. Elger, The significance of the 20-carbonyl group of progesterone in steroid receptor binding: a molecular dynamics and structure-based ligand design study, Steroids 68 (2003) 869-878.

[6] A.C. Herington, L.K. Chopin, P. Jeffery, L. de Amorim, T. Veveris-Lowe, L. Bui, J.A. Clements, Hormone-dependent cancers: new approaches to identification of potential diagnostic and/or therapeutic biomarkers, Asia-Pacific Journal of Molecular Biology and Biotechnology 18 (2010) 63-66.

[7] N. Zhu, Y. Ling, X. Lei, V. Handratta, A.M.H. Brodie, Novel P450 ${ }_{17 \alpha}$ inhibitors: 17(2'-oxazolyl)- and 17-(2'-thiazolyl)-androstane derivatives, Steroids 68 (2003) 603-611.

[8] J.P. Burkhart, C.A. Gates, M.E. Laughlin, R.J. Resvick, N.P. Peet, Inhibition of steroid C17(20) lyase with C-17-heteroaryl steroids, Bioorganic and Medicinal Chemistry 4 (1996) 1411-1420.

[9] D. Ondré, J. Wölfling, I. Tóth, M. Szécsi, J. Julesz, Gy Schneider, Stereoselective synthesis of some steroidal oxazolines, as potential inhibitors of $17 \alpha$-hydroxylase- $C_{17,20}$-lyase, Steroids 74 (2009) 1025-1032.

[10] Y.Z. Ling, J.S. Li, Y. Liu, K. Kato, G.T. Klus, A.M.H. Brodie, 17-Imidazolyl, pyrazolyl and isoxazolyl androstene derivatives, novel steroid inhibitors of human cytochrome $\left(\mathrm{C}_{17,20}\right.$-lyase ( $\left.\mathrm{P}_{550_{17 \alpha}}\right)$, Journal of Medicinal Chemistry 40 (1997) 3297-3304.

[11] Z. Iványi, J.Wölfling T. Görbe, M. Szécsi, T. Wittmann, Gy Schneider, Synthesis of regioisomeric $17 \beta-\mathrm{N}$-phenylpyrazolyl steroid derivatives and their inhibitory effect on $17 \alpha$-hydroxylase/C 17,20 -lyase, Steroids 75 (2010) 450-456.

[12] A.M.H. Brodie, V.C.O. Njar, Aromatase inhibitors and their application in breast cancer treatment, Steroids 65 (2000) 171-179.

[13] M.R. Yadav, P.M. Sabale, R. Giridhar, C. Zimmer, J. Haupenthal, R.W. Hartmann, Synthesis of some novel androstanes as potential aromatase inhibitors, Steroids 76 (2011) 464-470.

[14] V.C. Jordan, Tamoxifen: toxicities and drug resistance during the treatment and prevention of breast cancer, Annual Review of Pharmacology and Toxicology 35 (1995) 195-211.

[15] V.S. Pribluda, E.R. Gubish, T.M. LaVallee, A. Treston, G.M. Swartz, J.S. Green, 2-Methoxyestradiol: an endogenous antiangiogenic and antiproliferative drug candidate, Cancer and Metastasis Reviews 19 (2000) 173-179.
[16] L.R. Quadan, C.M. Perez-Stable, C. Anderson, G. D’lppolito, A. Herron, G.A Howard, A.B. Roos, 2-Methoxyestradiol induces G2/M arrest and apoptosis in prostate cancer, Biochemical and Biophysical Research Communications 285 (2001) 1259-1266.

[17] T.-L. Yue, X. Wang, C.S. Louden, S. Gupta, K. Pillarisetti, J.-L. Gu, T.K. Hart, P.G. Lysko, Z.G. Feuerstein, 2-Methoxyestradiol, an endogenous estrogen metabolite, induces apoptosis in endothelial cells and inhibits angiogenesis: possible role for stress-activated protein kinase signaling pathway and Fas expression, Molecular Pharmacology 51 (1997) 951-962.

[18] H. Seeger, F.-U. Deuringer, D. Wallwiener, A.O. Mueck, Breast cancer risk during HRT: influence of estradiol metabolites on breast cancer and endothelial cell proliferation, Maturitas 49 (2004) 235-240.

[19] A.O. Mueck, H. Seeger, 2-Methoxyestradiol-biology and mechanism of action, Steroids 75 (2010) 625-631.

[20] T. Mqoco, S. Marais, A. Joubert, Influence of estradiol analogue on cell growth, morphology and death in esophageal carcinoma cells, Biocell 34 (2010) $113-120$.

[21] A.O. Mueck, C. Lippert, H. Seeger, D. Wallwiener, Angiogenetic and antiangiogenetic effects of estradiol and its metabolites, Journal of Clinical and Basic Cardiology 4 (2001) 153-155.

[22] T.M. LaVallee, X.H. Zhan, C.J. Herbstritt, E.C. Kough, S.J. Green, S.V. Pribluda, 2 Methoxyestradiol inhibits proliferation and induces apoptosis independently of estrogen receptors $\alpha$ and $\beta$, Cancer Research 62 (2002) 3691-3697.

[23] N.J. Lakhani, M.A. Sarkar, J. Venitz, D.W. Figg, 2-Methoxyestradiol, a promising anticancer agent, Pharmacotherapy 23 (2003) 165-172.

[24] É. Frank, J. Molnár, I. Zupkó, Z. Kádár, J. Wölfling, Synthesis of novel steroida $17 \alpha$-triazolyl derivatives via $\mathrm{Cu}(\mathrm{I})$-catalyzed azide-alkyne cycloaddition, and an evaluation of their cytotoxic activity in vitro, Steroids 76 (2011) 1141-1148.

[25] J. Wölfling, E. Mernyák, É. Frank, G. Falkay, Á. Márki, R. Minorics, Gy Schneider, Synthesis and receptor-binding examinations of the normal and 13-epi-Dhomoestrones and their 3-methyl ethers, Steroids 68 (2003) 277-288.

[26] É. Frank, Zs. Kardos, J. Wölfling, Gy Schneider, Stereoselective synthesis of novel $\Delta^{5}$-androstenopyrazoline derivatives by $\mathrm{BF}_{3} \cdot \mathrm{OEt}_{2}$-induced intramolecular 1,3dipolar cycloaddition, Synlett (2007) 1311-1313.

[27] N.J. Lakhani, A. Sparreboom, X. Xu, T.D. Veenstra, J. Venitz, W.L. Dahut, W.D. Figg, Characterization of in vitro and in vivo metabolic pathways of the investigational anticancer agent, 2-methoxyestradiol, Journal of Pharmaceutical Sciences 96 (2007) 1821-1831.

[28] Z. Wang, D. Yang, A.K. Mohanakrishnan, P.E. Fanwick, P. Nampoothiri, E. Hamel, M. Cushman, Synthesis of B-ring homologated estradiol analogues that modulate tubulin polymerization and microtubule stability, Journal of Medicinal Chemistry 43 (2000) 2419-2429.

[29] P.N. Rao, J.W. Cessac, T.L. Tinley, S.L. Mooberry, Synthesis and antimitotic activity of novel 2-methoxyestradiol analogs, Steroids 67 (2002) 1079-1089.

[30] P.N. Rao, J.W. Cessac, A new, practical synthesis of 2-methoxyestradiols, Steroids 67 (2002) 1065-1070.

[31] P.N. Rao, J.W. Cessac, J.W. Boyd, A.D. Hanson, J. Shah, Synthesis and antimitotic activity of novel 2-methoxyestradiol analogs. Part III, Steroids 73 (2008) 171-183.

[32] J.H. Shah, G.E. Agoston, L. Suwandi, K. Hunsucker, V. Pribluda, X.H. Zhan, G.M. Swartz, T.M. LaVallee, A.M. Treston, Synthesis of 2- and 17-substituted estrone analogs and their antiproliferative structure-activity relationships compared to 2-methoxyestradiol, Bioorganic and Medicinal Chemistry 17 (2009) 7344-7352

[33] P.N. Rao, J.W. Cessac, J.W. Boyd, A.D. Hanson, J. Shah, Synthesis and antimitotic activity of novel 2-methoxyestradiol analogs. Part II, Steroids 73 (2008) $158-170$.

[34] L.S. Suwandi, G.E. Agoston, J.H. Shah, A.D. Hanson, X.H. Zhan, T.M. LaVallee, A.M Treston, Synthesis and antitumor activities of 3-modified 2-methoxyestradiol analogs, Bioorganic and Medicinal Chemistry Letters 19 (2009) 6459-6462.

[35] G.E. Agoston, J.H. Shah, L. Suwandi, A.D. Hanson, X. Zhan, T.M. LaVallee, V. Pribluda, A.M. Treston, Synthesis, antiproliferative, and pharmacokinetic properties of 3- and 17-double-modified analogs of 2-methoxyestradiol, Bioorganic and Medicinal Chemistry Letters 19 (2009) 6241-6244.

[36] M.P. Leese, F.L. Jourdan, K. Gaukroger, M.F. Mahon, S.P. Newman, P.A. Foster, et al., Structure-activity relationships of C-17 cyano-substituted estratrienes as anticancer agents, Journal of Medicinal Chemistry 51 (2008) 1295-1308.

[37] C. Bubert, M.P. Leese, M.F. Mahon, E. Ferrandis, S. Regis-Lydi, P.G. Kasprzyk, S.P. Newman, et al., 3,17-Disubstituted 2-alkylestra-1,3,5(10)trien-3-ol derivatives: synthesis, in vitro and in vivo anticancer activity, Journal of Medicinal Chemistry 50 (2007) 4431-4443.

[38] F. Jourdan, M.P. Leese, W. Dohle, E. Hamel, E. Ferrandis, S.P. Newman, et al., Synthesis, antitubulin, and antiproliferative SAR of analogues of 2methoxyestradiol-3,17-0,0-bis-sulfamate, Journal of Medicinal Chemistry 53 (2010) 2942-2951

[39] G.E. Agoston, J.H. Shah, T.M. LaVallee, X. Zhan, V.S. Pribluda, A.M. Treston, Synthesis and structure-activity relationships of modified analogs of 2methoxyestradiol, Bioorganic and Medicinal Chemistry 15 (2007) 7524-7537.

[40] A.J. Mancuso, S.-L. Huang, D. Swern, Oxidation of long-chain and related alcohols to carbonyls by dimethyl sulfoxide "activated" by oxalyl chloride, Journal of Organic Chemistry 43 (1978) 2480-2482.

[41] A.B. Edsall, A.K. Mohanakrishnan, D. Yand, P.E. Fanwick, E. Hamel, A.D. Hanson, G.E. Agoston, M. Cushman, Effects of altering the electronics of $2-$ methoxyestradiol on cell proliferation, on cytotoxicity in human cancer cell cultures, and on tubulin polymerization, Journal of Medicinal Chemistry 47 (2004) 5126-5139. 
[42] G. Panchapakesan, V. Dhayalan, N.D. Moorthy, N. Saranya, A.K. Mohanakrishnan, Synthesis of 2-substituted $17 \beta$-hydroxy/17-methylene estratrienes and their in vitro cytotoxicity in human cancer cell cultures, Steroids 76 (2011) 1491-1504.

[43] C. Li, W. Qiu, Z. Yang, J. Luo, F. Yang, M. Liu, J. Xie, J. Tang, Stereoselective synthesis of some methyl-substituted steroid hormones and their in vitro cytotoxic activity against human gastric cancer cell line MGC-803, Steroids 75 (2010) 859-869.

[44] R. Minorics, N. Bózsity, J. Wölfling, E. Mernyák, Gy. Schneider, Á. Márki, G. Falkay, I. Ocsovszki, I. Zupkó, Antiproliferative effect of normal and 13-epiD-homoestrone and their 3-methyl ethers on human reproductive cancer cell lines, Journal of Steroid Biochemistry 132 (2012) 168-175.

[45] T. Saloranta, I. Zupkó, J. Rahkila, Gy. Schneider, J. Wölfling, R. Leino, Increasing the amphiphilicity of an estradiol based steroid structure by Barbierallylation-ring-closing metathesis-dihydroxylation sequence, Steroids 77 (2012) 110-117

[46] S. Yoshida, A. Honda, Y. Matsuzaki, S. Fukushima, N. Tanaka, A. Takagiwa, Y. Fujimoto, H. Miyazaki, G. Salen, Anti-proliferative action of endogenous dehydroepiandrosterone metabolites on human cancer cell lines, Steroids 68 (2003) 73-83.

[47] Y. Matsuzaki, A. Honda, Dehydroepiandrosterone and its derivatives: potentially novel anti-proliferative and chemopreventive agents, Current Pharmaceutical Design 12 (2006) 3411-3421.

[48] N. Dhingra, T.R. Bhardwaj, N. Mehta, T. Muklopadhyay, A. Kumar, M. Kumar, Synthesis, antiproliferative activity, acute toxicity and assessment of the antiandrogenic activities of new androstane derivatives, Archives of Pharmacal Research 34 (2011) 1055-1063.

[49] E.A. Djurendić, M.P. Zaviš, M.N. Sakač, J.J. Čanadi, V.V. Kojić, G.M. Bogdanović, K.M. Penov Gaši, Synthesis and antitumor activity of new D-seco and D-homo androstane derivatives, Steroids 74 (2009) 983-988.

[50] R.J. Santen, Inhibition of aromatase: insight from recent studies, Steroids 72 (2007) 31-40

[51] R.W. Brueggemeier, J.C. Hackett, E.S. Diaz-Cruz, Aromatase inhibitors in the treatment of breast cancer, Endocrine Reviews 26 (2005) 331-345.

[52] R. McCague, M.G. Rowlands, Conformational analysis of the aromatase inhibitor 3-ethyl-3(4-pyridyl)piperidine-2,6-dione (Rogletimide) and discovery of potent 5-alkyl derivatives, Journal of Medicinal Chemistry 35 (1992) 3699-3704.

[53] K.M.P. Gaši, M.D.D. Brenesel, E.A. Djurendić, M.N. Sakač, JJ. Daljev, T. Armbruster, S. Andrić, D.M. Sladić, T.T. Božić, I.N. Novaković, Z.D. Juranić, Synthesis and biological evaluation of some 17-picolyl and 17-picolinylidene androst-5ene derivatives, Steroids 72 (2007) 31-40.

[54] E. Djurendić, J. Daljev, M. Sakač, J. Čanadi, S.J. Šanta, S. Andrić, O. Klisurić, V. Kojić, G. Bogdavović, M. Djurendić-Brenesel, S. Novaković, K.P. Gaši, Synthesis of some epoxy and/or $N$-oxy 17 -picolyl and 17-picolinylidene-androst-5-ene derivatives and evaluation of their biological activity, Steroids 73 (2008) 129-138.

[55] D. Miljković, K. Gaši, M. Kindjer, S. Stanković, B. Ribar, Partial syntheses of 21,27-bisnordemissidine from epiandrosterone and dehydroepiandrosterone acetates. Crystal and molecular structure of 21,27-bisnordemissidine hydrobromide, Croatica Chemica Acta 58 (1985) 721-736.

[56] D. Miljković, K. Gaši, 3ß-Acetoxy-17-picolinylidene-5-androstene-16-one: the key intermediate in 21,27-bisnorsolanidine synthesis, Bulletin de la Société Chimique Beograd 46 (1981) 263-268.

[57] J. Wölfling, A. Magyar, Gy. Schneider, Synthesis of novel D-seco-pregnenes, Monatshefte fur Chemie 134 (2003) 1387-1393.

[58] É. Frank, Z. Mucsi, M. Szécsi, I. Zupkó, J. Wölfling, Gy. Schneider, Intramolecular approach to some new D-ring-fused steroidal isoxazolidines by 1,3-dipolar cycloaddition: synthesis, theoretical and in vitro pharmacological studies, New Journal of Chemistry 34 (2010) 2671-2681.

[59] F. Himo, T. Lowell, R. Hilgraf, V.V. Rostovtsev, L. Noodleman, K.B. Sharpless, V.V. Fokin, Copper(I)-catalyzed synthesis of azoles, DFT study predicts unprecedented reactivity and intermediates, Journal of the American Chemical Society 127 (2005) 210-216.

[60] D. Kovács, Z. Kádár, G. Mótyán, Gy. Schneider, J. Wölfling, I. Zupkó, É. Frank, Synthesis, characterization and biological evaluation of some novel 17-isoxazoles in the estrone series, Steroids 77 (2012) 1075-1085.

[61] Ch Camoutsis, S. Nikolaroupoulos, Steroidal isoxazoles, isoxazolines and isoxazolidines, Journal of Heterocyclic Chemistry 35 (1998) 731-759.

[62] A.H. Banday, B.P. Mir, I.H. Lone, K.A. Suri, H.M.S. Kumar, Studies on novel Dring substituted steroidal pyrazolines as potential anticancer agents, Steroids 75 (2010) 805-809.
[63] Z. Iványi, N. Szabó, J. Huber, J. Wölfling, I. Zupkó, M. Szécsi, Gy. Schneider, Synthesis of D-ring-substituted $\left(5^{\prime} R\right)$ - and $\left(5^{\prime} S\right)-17 \beta$-pyrazolinylandrostene epimers and comparison of their potent anticancer activities, Steroids 77 (2012) 566-574.

[64] D. Thibeault, J. Roy, P. DeRoy, D. Poirier, Chemical synthesis of $2 \beta$-amino$5 \alpha$-androstane- $3 \alpha, 17 \beta$-diol $N$-derivatives and their antiproliferative effect on HL-60 human leukemia cells, Bioorganic and Medicinal Chemistry 16 (2008) 5062-5077.

[65] J. Roy, R. Maltais, H. Jegham, D. Poirier, Libraries of $2 \beta$ - $(N$-substituted piperazino) $-5 \alpha$-androstane- $3 \alpha, 17 \beta$-diols: chemical synthesis and cytotoxic effects on human leukemia HL-60 cells and on normal lymphocytes, Molecular Diversity 15 (2011) 317-339.

[66] K.R. Lee, N. Kozukue, J.S. Han, J.H. Park, E.Y. Chang, E.J. Baek, J.S. Chang, M. Friedman, Glycoalkaloids and metabolites inhibit the growth of human colon (HT29) and liver (HepG2) cancer cells, Journal of Agricultural and Food Chemistry 52 (2004) 2832-2839.

[67] Y. Lavie, T. Harel-Orbital, W. Gaffield, M. Liscovitch, Inhibitory effect of steroidal alkaloids on drug transport and multidrug resistance in human cancer cells, Anticancer Research 21 (2001) 1189-1194.

[68] É. Frank, Z. Mucsi, I. Zupkó, B. Réthy, G. Falkay, Gy. Schneider, J. Wölfling, Efficient approach to androstene-fused arylpyrazolines as potent antiproliferative agents. experimental and theoretical studies of substituent effects on $\mathrm{BF}_{3}$ catalyzed intramolecular $[3+2]$ cycloadditions of olefinic phenylhydrazones, Journal of the American Chemical Society 131 (2009) 3894-3904.

[69] R. Minorics, T. Szekeres, G. Krupitza, P. Saiko, B. Giessrigl, J. Wölfling, É. Frank I. Zupkó, Antiproliferaive effects of some novel synthetic solanidine analogs on HL-60 human leukemia cells in vitro, Steroids 76 (2011) 156-162.

[70] D.R. Buckle, C.J. Rockell, H. Smith, B.A. Spicer, Piperazinylalkoxy[1 benzopyrano[2,3-d]-1,2,3-triazol-9(1H)-ones with combined $\mathrm{H} 1$ antihistamine and mast cell stabilizing properties, Journal of Medicinal Chemistry 29 (1986) 2262-2267.

[71] R. Alvarez, S. Velazquez, A. San-Felix, S. Aquaro, E. De Clercq, C.F. Perno, et al. 1,2,3-Triazole-[2',5'-bis-O-(tertbutyldimethylsilyl)-beta-D-ribofuranosyl]$3^{\prime}$-spiro-5" $5^{\prime \prime} 4^{\prime \prime}$-amino-1", $2^{\prime \prime}$-oxathiole $2^{\prime \prime}, 2^{\prime \prime}$-dioxide) (TSAO) analogues: synthesis and anti-HIV-1 activity, Journal of Medicinal Chemistry 37 (1994) 4185-4194.

[72] V.C.O. Njar, G.T. Klus, A.M.H. Brodie, Nucleophilic vinylic “addition-elimination" substitution reaction of $3 \beta$-acetoxy-17-chloro-16-formylandrosta-5,16-diene: a novel and general route to 17 -substituted steroids. Part 1 . Synthesis of novel 17-azolyl- $\Delta^{16}$ steroids; inhibitions of $17 \alpha$-hydroxylase/17,20lyase (17 $\alpha$-lyase), Bioorganic and Medicinal Chemistry Letters 6 (1996) 2777-2782.

[73] V.V. Rostovtsev, L.G. Green, V.V. Fokin, K.B. Sharpless, A stepwise Huisgen cycloaddition process: copper(I)-catalyzed regioselective ligation of azides and terminal alkynes, Angewandte Chemie International Edition 41 (2002) 2596-2599.

[74] C.W. Tornøe, C. Christensen, M. Meldal, Peptidotriazoles on solid phase: [1,2,3] triazoles by regiospecific copper(I)-catalyzed 1,3-dipolar cycloadditions of terminal alkynes to azides, Journal of Organic Chemistry 67 (2002) 3057-3064.

[75] M. Meldal, C.W. Tornøe, Cu(I)-catalyzed azide-alkyne cycloaddition, Chemical Reviews 108 (2008) 2952-3015.

[76] A.H. Banday, S.A. Shameem, B.D. Gupta, H.M.S. Kumar, D-ring substituted 1,2,3-triazolyl 20-keto pregnanes as potential anticancer agents: synthesis and biological evaluation, Steroids 75 (2010) 801-804.

[77] Z. Kádár, D. Kovács, É. Frank, Gy. Schneider, J. Huber, I. Zupkó, T Bartók, J. Wölfling, Synthesis and in vitro antiproliferative activity of nove androst-5-ene triazolyl and tetrazolyl derivatives, Molecules 16 (2011) 4786-4806.

[78] B.Y. Lee, S.R. Park, H.B. Jeon, K.S. Kim, A new solvent system for efficient synthesis of 1,2,3-triazoles, Tetrahedron Letters 47 (2006) 5105-5109.

[79] Z. Kádár, J. Molnár, Gy. Schneider, I. Zupkó, É. Frank, A facile “click” approach to novel $15 \beta$-triazolyl- $5 \alpha$-androstane derivatives and an evaluation of their antiproliferative activities in vitro, Bioorganic and Medicinal Chemistry 20 (2012) 1396-1402

[80] I. Cherny, V. Pouzar, O. Lapcik, R. Hampl, Addition of azoimide to unsaturated ketones in the steroid series-synthesis of (oxy-3-oxo-5 $\alpha$-androstan-15 $\beta$ yl)succinamoic acid and its evaluation as hapten for dihydrotestosterone immuno analysis, Collection of Czechoslovak Chemical Communications 62 (1997) 1931-1939.

[81] Z. Kádár, Á. Baji, I. Zupkó, T. Bartók, J. Wölfling, É. Frank, Efficient approach to novel $1 \alpha$-triazolyl- $5 \alpha$-androstane derivatives as potent antiproliferative agents, Organic \& Biomolecular Chemistry 9 (2011) 8051-8057. 